\title{
Modulation of Organogenesis and Somatic Embryogenesis by Ethylene: An Overview
}

\author{
Mariana Neves $^{1}\left(\mathbb{D}\right.$, Sandra Correia ${ }^{1}$, Carlos Cavaleiro ${ }^{2}(\mathbb{D})$ and Jorge Canhoto $^{1, *(D)}$ \\ 1 Center for Functional Ecology, Department of Life Sciences, University of Coimbra, \\ 3000-456 Coimbra, Portugal; mariananevespt@gmail.com (M.N.); sandraimc@ci.uc.pt (S.C.) \\ 2 CIEPQPF, Faculty of Pharmacy, University of Coimbra, Pólo das Ciências da Saúde, \\ Azinhaga de Santa Comba, 3000-548 Coimbra, Portugal; cavaleir@ff.uc.pt \\ * Correspondence: jorgecan@uc.pt
}

Citation: Neves, M.; Correia, S.; Cavaleiro, C.; Canhoto, J. Modulation of Organogenesis and Somatic Embryogenesis by Ethylene: An Overview. Plants 2021, 10, 1208. https://doi.org/10.3390/ plants10061208

Academic Editor: Sharyn Perry

Received: 17 May 2021

Accepted: 9 June 2021

Published: 14 June 2021

Publisher's Note: MDPI stays neutral with regard to jurisdictional claims in published maps and institutional affiliations.

Copyright: (C) 2021 by the authors. Licensee MDPI, Basel, Switzerland. This article is an open access article distributed under the terms and conditions of the Creative Commons Attribution (CC BY) license (https:// creativecommons.org/licenses/by/ $4.0 /)$.
Abstract: Ethylene is a plant hormone controlling physiological and developmental processes such as fruit maturation, hairy root formation, and leaf abscission. Its effect on regeneration systems, such as organogenesis and somatic embryogenesis (SE), has been studied, and progress in molecular biology techniques have contributed to unveiling the mechanisms behind its effects. The influence of ethylene on regeneration should not be overlooked. This compound affects regeneration differently, depending on the species, genotype, and explant. In some species, ethylene seems to revert recalcitrance in genotypes with low regeneration capacity. However, its effect is not additive, since in genotypes with high regeneration capacity this ability decreases in the presence of ethylene precursors, suggesting that regeneration is modulated by ethylene. Several lines of evidence have shown that the role of ethylene in regeneration is markedly connected to biotic and abiotic stresses as well as to hormonalcrosstalk, in particular with key regeneration hormones and growth regulators of the auxin and cytokinin families. Transcriptional factors of the ethylene response factor (ERF) family are regulated by ethylene and strongly connected to SE induction. Thus, an evident connection between ethylene, stress responses, and regeneration capacity is markedly established. In this review the effect of ethylene and the way it interacts with other players during organogenesis and somatic embryogenesis is discussed. Further studies on the regulation of ERF gene expression induced by ethylene during regeneration can contribute to new insights on the exact role of ethylene in these processes. A possible role in epigenetic modifications should be considered, since some ethylene signaling components are directly related to histone acetylation.

Keywords: ethylene biosynthesis; ethylene inhibitors; in vitro culture; plant hormones; S-adenosylmethionine; stress responses

\section{Introduction}

Micropropagation has been studied and developed through the years, and is currently one of the best alternatives for large-scale propagation and conservation of a wide range of plant species [1]. In practical terms, micropropagation is the culture of plant cells, tissues, or organs in a well-defined culture medium, under controlled aseptic conditions [2]. Several in vitro culture methods have been developed and, in combination with molecular techniques, have allowed for the multiplication of selected genotypes with better resistance to diseases and stress tolerance capacity [1]. Advances in plant tissue culture have also provided a deep analysis of several developmental plant processes and have helped to understand some of their molecular mechanisms [3].

Apart from the genotype and the type of explant, nutritional and environmental conditions are critical factors to achieve an optimal response from plant tissues. Mineral composition, carbon source, plant growth regulators (PGRs), gelling agents, pH, light, temperature, and also the gaseous environment are the factors to take into consideration for the success of the different in vitro plant propagation and regeneration processes [1]. 
Plant regeneration systems, such as organogenesis and somatic embryogenesis (SE) are well-known micropropagation processes based on plant cells pluripotency/totipotency. In organogenesis, plant organs, such as shoots, roots, and even flowers, can be formed from cultured explants. However, for micropropagation purposes, the most interesting is de novo shoot meristem formation followed by shoot growth and rooting. SE is a more complex developmental pathway by which bipolar structures identical to zygotic embryos are developed from somatic cells through a complex dedifferentiation process, followed by totipotency acquisition and formation of somatic embryos $[3,4]$. The presence of PGRs in the culture media-in particular, auxins and cytokinins-is required for the success of plant regeneration, since a balance between both hormones contributes to enhance the in vitro regenerative capacity of a myriad of plant species [3]. While these PGRs are deliberately placed in the culture medium in a well-defined added concentration, and a dose-response assay can be easily evaluated, the role of gaseous compounds, such as the hormone ethylene, is more difficult to analyze. This gas is usually liberated during the in vitro culture of plant tissues accumulating in the surrounding atmosphere when closed vessels are used. Therefore, its presence and consequent accumulation in culture vessels is a consequence of the method and not of a deliberate addition [5]. Thus, understanding whether ethylene influences in vitro culture is relevant for the improvement of in vitro regeneration processes and somehow may explain why some species or tissues seem to be more recalcitrant than others.

Taking this into consideration, this review presents a general overview of the ethylene effect on the main in vitro regeneration processes, revising and discussing the studies that have been published over the years. A brief overview of ethylene's biosynthesis and signaling pathways and its different modulations are also presented herein.

\section{Ethylene: Biosynthesis and Signaling Pathway}

The plant hormone ethylene, $\mathrm{C}_{2} \mathrm{H}_{4}$, is a simple, small, and gaseous molecule synthetized and released by plant tissues. Despite its simplicity, this hormone has a crucial role in controlling several physiological and developmental processes, ranging from plant growth to fruit ripening [6]. Its biosynthesis was intensively studied in the second half of the 20th century, the period in which methionine was found as an ethylene precursor by Lieberman et al. [7]. Later on, Adams and Yang [8,9] identified and demonstrated that s-adenosylmethionine (SAM) and 1-aminocyclopropane-1-carboxylic acid (ACC) were the intermediates in the conversion of methionine to ethylene. The same authors also proposed that the methionine involved in ethylene production was recycled by a set of reactions termed the methionine cycle, nowadays known as the Yang cycle. The identification of the ethylene precursors was the major breakthrough for the establishment of the ethylene biosynthetic pathway, as it is known today. In a general overview, ethylene biosynthesis begins with methionine, which is converted to ethylene through three successive enzymatic reactions (Figure 1). In the first reaction, methionine is converted to SAM by SAM synthetase (SAMS), then SAM is converted to ACC by ACC synthase (ACS), and finally ACC oxidase (ACO) degrades ACC, releasing ethylene [10].

The effect of this hormone on plant tissues is the result of a complex subsequent signaling pathway in which some molecular mechanisms are not yet fully understood. Diverse studies with Arabidopsis thaliana allowed the identification and characterization of the signaling ethylene components, such as the ethylene receptors. Five ethylene receptor isoforms have been identified, denominated ETHYLENE RESISTANT1 (ETR1), ETR2, ETHYLENE INSENSITIVE4 (EIN4), ETHYLENE RESPONSE SENSOR1 (ERS1), and ERS2. Despite some structural differences, all the isoforms are homodimers, constituted by two monomers, stabilized by two disulfide bonds. The ethylene-binding domain is highly conserved at the $\mathrm{N}$-terminus. This ethylene-binding site is formed by three transmembrane $\alpha$-helices of each monomer, that together coordinate at least a copper ion, $\mathrm{Cu}(\mathrm{I})$ (see [11] for a detailed characterization). ETR1 in Arabidopsis was not only the first ethylene receptor identified but also the first plant hormone receptor identified and cloned [12,13]. Further 
studies with ETR1 have allowed the identification of key components responsible for the high affinity of this hormone to its receptors. Therefore, it is known that $\mathrm{Cu}(\mathrm{I})$ has a fundamental role since it acts as a cofactor, mediating the binding of ethylene to its receptors [14]. All the receptor isoforms coordinate $\mathrm{Cu}(\mathrm{I})$ in their transmembrane portion (ethylene-binding site). In the absence of this cofactor, ethylene binding is compromised and, consequently, this hormone is not perceived by plant tissues [11].

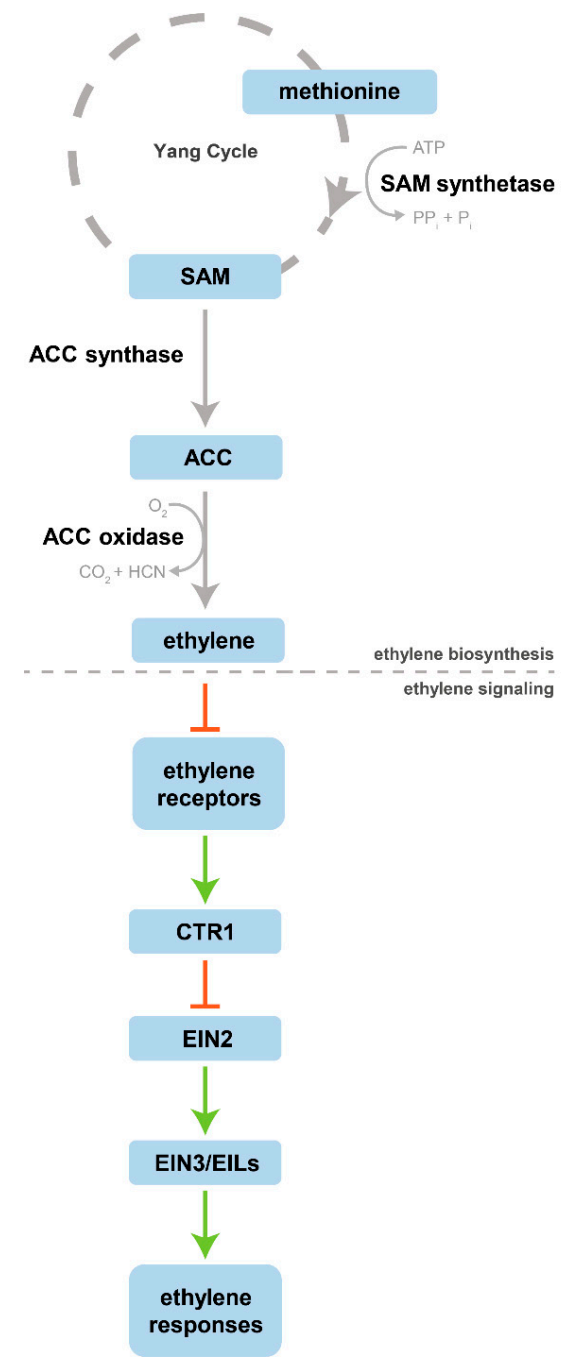

Figure 1. Schematic overview of ethylene biosynthesis and the canonical signaling pathway. Ethylene acts as an inverse agonist, inhibiting its receptors. This inhibition leads to a reduction in CTR1 activity, which allows the set of reactions downstream to occur, culminating in ethylene responses. The different pathways are separated by a dashed line. Inhibition steps are marked with an inhibitory arrow (red). Based on the signaling models of Wang et al. [10] and Binder [15].

Recently, Binder [15] reviewed the canonical ethylene signaling pathway in Arabidopsis and suggested that ethylene signal transduction may be even more complex. To summarize - canonically, ethylene, once biosynthesized, acts as an inverse agonist, binding and inhibiting its receptors in the endoplasmic reticulum (ER) membrane. Downstream, ethylene receptors interact with the serine/threonine-protein kinase CONSTITUTIVE TRIPLE RESPONSE1 (CTR1), inhibiting its activity. Therefore, CTR1 can no longer phosphorylate EIN2, leading to a reduction in EIN2 ubiquitination and consequently resulting in an increase of EIN2 levels. The lack of phosphorylation also promotes the cleavage of the EIN2 C-terminus (EIN2-C) from the N-terminus by an unknown protease. EIN2-C functions as a positive regulator, moves from the ER to the nucleus, increasing the levels and the activity of the transcription factors EIN3, ETHYLENE INSENSITIVE3-LIKE1 (EIL1) 
and EIL2, which lead to transcriptional changes and consequently promote ethylene responses $[15,16]$. As the ethylene signaling pathway is not the main focus of this review it will not be discussed in detail, but for readers who desire detailed information, recent reviews by Ju and Chang [16] and Binder [15] are recommended. A brief outline on ethylene biosynthesis and consequent signaling is present herein (Figure 1).

\section{Culture Vessels and Ethylene Accumulation}

The use of closed culture vessels to prevent contaminations is one of the requirements of in vitro culture. Test tubes, glass vials, Petri dishes, and boxes made of polycarbonate or polypropylene are some examples of vessels used in micropropagation. These vessels can then be closed with different types of closures, such as screw lids, polycarbonate or polypropylene lids, plastic film, Parafilm, and cotton plugs, among others. The different types of vessels and, in particular, the different possible closures allow a greater or lesser gas exchange rate with the external environment $[17,18]$ without compromising aseptic conditions.

To detect and measure ethylene, several methods can be used, such as gas-chromatography (GC), electrochemical sensing, and optical detection. All of these detection methods have their advantages and limitations. Therefore, the selection of the most suitable method will depend on the purpose of each study. For instance, when sensitivity and real-time detection is needed, optical detection is recommended. Whether, in addition to ethylene, other gases need to be quantified, GC will be the most suitable method [19]. GC is the oldest and the most commonly used method of ethylene detection according to the literature, with its first application reported by Huelin and Kennett [20]. In in vitro studies using GC to measure ethylene (e.g., ethylene accumulation in culture vessels or the rate of ethylene production by plant tissues), sealed vessels with a rubber septum are required. This type of closure allows the withdrawal of gas samples from the headspace, which can then be detected and analyzed [5].

Most vessels currently used in micropropagation seem to allow gas exchanges. This aspect prevents the excessive accumulation of ethylene and other gases in the culture atmosphere. However, when exogenous treatments of ethylene are performed, its loss should be considered, especially in studies entailing longer culture periods. Jackson et al. [21] studied the ventilation capacity of different vessels and sealing methods, monitoring the rate loss of ethylene previously injected. For instance, in the same type of vessel (polycarbonate box with a polypropylene lid), vessels that were loosely closed (i.e., using only the respective lid of the vessel) lost half of the injected ethylene in 1-2 h, while tightly closed vessels (i.e, using two layers of Nescofilm between the join of the vessel and the lid) increased the half-time of ethylene depletion to $16 \mathrm{~h}$. Glass vessels with glass lids were also tested. Whereas the loose sealing presented the same results as the other vessels (approximately $2 \mathrm{~h}$ ), the tight sealing increased the half-time of the ethylene depletion to $100 \mathrm{~h}$. The authors also monitored the accumulation of ethylene produced from plant tissues during 28 days. Ethylene accumulated in all vessels, with a greater accumulation in tightly closed vessels, as expected, and seemed to decrease during the last days of the culture.

The amount of ethylene accumulated in the atmosphere of culture will depend on both the gas exchange rate between the vessel and the exterior and the rate of ethylene production by plant tissues themselves [5]. Note that even though these gas exchanges occur and thus some ethylene is lost, its accumulation in culture vessels persists, to a greater or lesser extent, and may be a limiting factor for the success of in vitro culture; in particular, for the most ethylene-sensitive species. In this regard, understanding the effect of this hormone in plant tissues can be assessed by a chemical or a genetic approach, a subject that will be reviewed in the next two sections.

\section{Chemical Modulation of Ethylene Responses}

All the knowledge acquired regarding ethylene biosynthetic and signaling pathways have allowed both modulation of its biosynthesis and perception in plant tissues, therefore 
enhancing, decreasing, or inhibiting ethylene responses. Manipulating these responses is a crucial step to understanding the influence of this hormone in a myriad of physiological processes. In this context, several chemical inhibitors and enhancers of ethylene action have been studied and widely used.

Regarding chemical inhibitors, they can be divided into two main categories, depending on whether they inhibit its biosynthetic pathway or its signaling pathway [22].

ACS and ACO enzymes are the key targets in the inhibition of ethylene biosynthesis. Compounds such as aminoethoxyvinylglycine (AVG) and aminooxyacetic acid (AOA) are the main ACS inhibitors used through the diverse ethylene studies. These two compounds revealed an effective inhibition of ACS activity with significant reductions in the production of ACC and, consequently, ethylene [23-25]. ACS is a pyridoxal phosphate-dependent enzyme for the conversion of SAM to ACC [24] and both AVG and AOA are inhibitors of pyridoxal phosphate-mediated reactions [24,26] - the reason for the great effectiveness of this inhibition. However, Schaller and Binder [22] stressed the non-specificity of both compounds and their undesirable off-target effects. AVG and AOA inhibit other pyridoxal phosphate-dependent enzymes, such as tryptophan aminotransferase, involved in indole3-acetic acid (IAA, endogenous auxin) biosynthesis [27].

Regarding the ACO enzyme, cobalt ions, $\mathrm{Co}(\mathrm{II})$, and aminoisobutyric acid (AIB) are known for inhibiting its activity $[25,28,29]$. ACO is a member of the 2-oxoglutaratedepedent dioxygenase superfamily, which depends on Fe(II) as a cofactor to convert ACC into ethylene [30]. $\mathrm{Co}(\mathrm{II})$ is reported as an effective inhibitor of ACO activity due to its competitive inhibition with Fe(II) for the active site [31]. AIB, on the other hand, acts as an analogue of ACC, competitively inhibiting the conversion of ACC into ethylene [28]. Salicylic acid also inhibits ACO activity [32] and for this reason has been also used as an ethylene modulator, albeit to a lesser extent.

Due to the non-specific effect of some compounds, the demand for specific ethylene biosynthesis inhibitors has increased. Therefore, novel inhibitors of ACS and ACO are being studied using a phenotype-based screening approach in Arabidopsis [33,34], identifying small chemical compounds that specifically inhibit these enzymes.

The main target of ethylene signaling inhibitors are ethylene receptors [22]. One of the strategies to inhibit ethylene action in plant tissues is the use of silver ions, $\mathrm{Ag}(\mathrm{I})$, usually applied as silver nitrate $\left(\mathrm{AgNO}_{3}\right)$ or silver thiosulfate (STS). $\mathrm{Ag}(\mathrm{I})$ is a widely used potent inhibitor of ethylene perception [35], due to the replacement of the $\mathrm{Cu}(\mathrm{I})$ cofactor required for ethylene binding, thus blocking ethylene signaling [36]. Despite the highly conserved ethylene-binding domain among all ethylene receptors isoforms [11], $\mathrm{Ag}(\mathrm{I})$ seems to replace $\mathrm{Cu}(\mathrm{I})$ mainly at ETR1, however, this inhibition is sufficient to inhibit ethylene responses [37]. Despite being one of the most common inhibitors used, silver has some phytotoxicity already recognized. Silver ions, applied as $\mathrm{AgNO}_{3}$, induced oxidative stress in seedlings of mustard [38] and in leaves and roots of tobacco plants [39]. Furthermore, treatments with $\mathrm{AgNO}_{3}$ reduced some physiological parameters, such as chlorophyll a content and plant biomass in wheat [40] and Spirodela polyrhiza plants [41]. In a similar way to AVG and AOA, silver also has off-target effects [22], increasing auxin efflux [42].

Gaseous compounds such as 1-methylcyclopropene (1-MCP), trans-cyclooctene (TCO) and 2,5-norbornadiene (NBD) also can be used as inhibitors of ethylene receptors [22]. These olefin compounds are competitive inhibitors, competing with ethylene for its receptors. From the three compounds, 1-MCP is the best alternative to control ethylene responses due to its effective inhibition at extremely low concentrations, prolonged effect and non-toxicity, triggering lower possible side-effects [43]. These characteristics make 1-MCP one of the best compounds to apply in ethylene studies due to its lower rate of off-target effects [22]. Due to the gaseous nature of these receptor inhibitors, the use of gas-tight chambers is required for their maintenance in the culture atmosphere (see [22] for chambers examples). 
It should be noted that the use of inhibitors of ethylene biosynthesis compared with inhibitors of ethylene signaling do not protect against exogenous sources of ethylene. This fact can offer an advantage by allowing the reversion of their effect in plant tissues. For instance, the application of exogenous ethylene to the culture atmosphere, and if only ACS was inhibited, exogenous treatments with ethylene's intermediate ACC can also be used [22].

Apart from the use of both classes of inhibitors mentioned above, changing the ethylene atmospheric concentration is another relevant strategy, particularly in in vitro tissue cultures due to the use of closed vessels. In this regard, pure ethylene or its precursors can be applied in order to enhance ethylene action in plant tissues [5]. The ethylene precursor ACC has been widely used in vitro, since it promotes an increase of ethylene biosynthesis by ACO, enhancing ethylene production [44]. Another ethylene precursor, 2-chloroethylphosphonic acid, commonly known as ethephon (ETH), has been proven to cause responses similar to those of exogenous ethylene treatments effectively [45] and, for this reason, has also been widely used throughout several studies. Methylglyoxal bis(guanylhydrazone) (MGBG) is also used to promote ethylene biosynthesis, albeit to a lesser extent, due to inhibition of polyamine biosynthesis. Polyamines synthesis use SAM as precursor and its inhibition stimulates ethylene production [46]. On the other hand, it is also possible to remove ethylene from culture atmosphere using compounds such as mercuric perchlorate $\left(\mathrm{HgClO}_{4}\right)$ and potassium permanganate $\left(\mathrm{KMnO}_{4}\right.$, [5]). Mercuric perchlorate forms complexes with ethylene [47], whereas potassium permanganate oxidizes ethylene [48]. Both act as ethylene absorbents, therefore decreasing the ethylene concentration in the culture atmosphere and, consequently, the action of ethylene on plant tissues. A schematic diagram of some of the principal ethylene modulators and their points of action is presented herein (Figure 2).

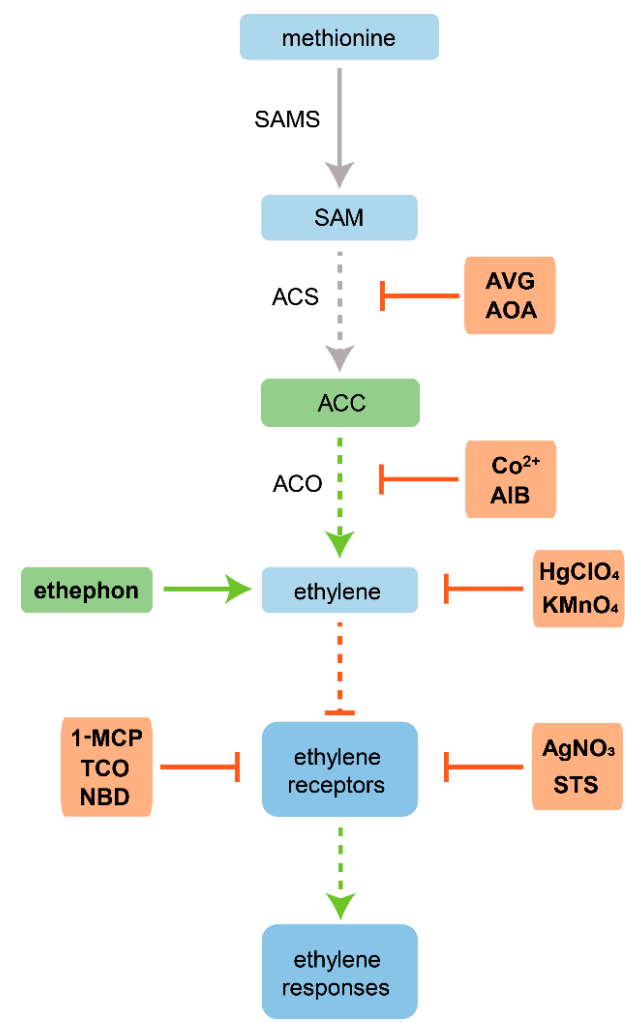

Figure 2. Schematic diagram of some of the principal ethylene modulators and their points of action. Ethylene precursors are shown in green followed by a green arrow. Inhibitors of ethylene biosynthesis and action are shown in orange followed by an inhibitory arrow (red). Dashed arrows indicate the pathway steps that can be affected by modulation. Based on Schaller and Binder [22]. 


\section{Genetic and Epigenetic Modulations of Ethylene Responses}

Aside from the chemical modulation previously reviewed, the development of molecular techniques has helped us to understand and modulate the effect of this hormone on plant tissues while contributing to detailed insights on the role of each component of the ethylene biosynthesis and signaling pathways. With genetic engineering it has been possible to alter ethylene levels in plant tissues via either or both the ACS and ACO enzymes, or its perception through the components of its signaling [49]. Studies using plant mutants with altered ethylene sensitivity or production $[50,51]$ as well as transgenic plants with altered ethylene biosynthesis or perception [49] have been important contributions for the characterization of ethylene signaling and its responses as they are currently known.

Different mutants in Arabidopsis, with different mutations regarding the components of ethylene biosynthesis or signaling pathways, are well characterized. Depending on the type of mutation, the plant mutant can exhibit distinct phenotypes, such as ethylene insensitivity [13], ethylene constitutive responses (i.e., exhibiting the phenotype observed in plants treated with ethylene [52]), and ethylene overproduction [53]. For instance, the etr1-1 mutant, characterized by a missense mutation at the ETR1 gene, exhibits insensitivity to ethylene. This mutation alters a single amino acid at the N-terminus of the ETR1 receptor in the ethylene-binding domain [12,13] and for this reason eliminates the capability to bind ethylene [54], comparable to what happens in Ag(I) treatments. Similar phenotypes are exhibited in both etr2-1 and ein 4- 1 mutants, with similar mutations to that of etr1-1 in the ETR2 and EIN4 genes, respectively $[55,56]$. These similarities seem to be in agreement with the conservation of the ethylene-binding domain among the receptor's isoforms. On the other hand, the ctr1-1 mutant exhibits an ethylene constitutive response. This mutant is characterized by a single amino acid substitution in the serine/threonineprotein kinase CTR1 at the highly conserved kinase residues, resulting in a disruption of its catalytic domain [52] and consequently inactivating its function. Regarding the ethylene biosynthesis, the recessive mutant eto 1 and the dominant mutants eto 2 and eto 3 are characterized by increasing the stability of ACS, exhibiting an ethylene overproduction phenotype $[50,53,57]$. These ethylene-overproducing mutants are characterized by mutations affecting the posttranscriptional regulation of ACS5 and ACS9 isoforms, resulting in an increase of ethylene biosynthesis [53].

Beyond the mutants described, modulating the amount of ethylene produced or its perception, through the creation of transgenic lines in several species, has been a goal of genetic engineering, particularly for commercial purposes [49] due to the effect of excessive amounts of ethylene in fruit ripening and senescence. Therefore, transgenic approaches have been applied using diverse molecular techniques, which have allowed the silencing or the overproducing of the enzymes involved in ethylene biosynthesis, leading to different accumulations of this hormone in plant tissues. Most of these strategies entail the downregulation of $A C S$ or $A C O$ expression, leading to a reduction of its enzymatic activity and consequent reduction of ethylene production [30]. This modulation can be achieved using sense- or antisense-mediated gene silencing, co-suppression, or by using an RNA interference (RNAi) approach, with several studies carried out in several plant species $[30,49,58,59]$. Regarding an ethylene overproduction strategy, the overexpression of the $A C O$ gene was achieved in poplar [60] and in safflower [61], by transforming these plants with an overexpression vector containing the open reading frame of the specific ACO. Note that the ACO enzyme is the most studied and suitable target regarding genetic alterations of ethylene biosynthesis due to its reduced risk of interfering with other metabolic pathways, such as the methionine cycle and ACC metabolism [30].

A promising strategy to alter ethylene responses is the use of the genome editing system CRISPR/Cas9, a potent system capable of generating efficiently mutations in specific targeted genes in plants [62]. In fact, very recently, Xu et al. [63] reported successful generation of $A C O$-edited mutants in petunia, which exhibited lower ethylene production through the editing of the specific ACO gene using the CRISPR/Cas9 system. 
Currently, using plants with these genetic alterations can give us a more specific approach to the effects of this hormone regarding both in vivo and in vitro processes, with a decrease of possible off-targets. Therefore, these plants, especially the Arabidopsis mutants, are currently important models in the study of the impact of ethylene in the success of several in vitro processes. However, the use of transgenic or mutant plants involves more extensive and expensive protocols, compared to the use of chemical inhibitors. A chemical approach is easier to manipulate and its effect can be also easily reverted (e.g., changing plant tissues to a non-treatment medium). Furthermore, these chemicals can be easily applied only at specific points of each in vitro process.

Epigenetic regulation in plants is associated with plant plasticity and the plant's ability to survive in response to stress. Variations in gene expression by DNA methylation, histone modification, and noncoding RNAs are directly associated with epigenetic modifications [64]. Studies related to the involvement of ethylene on epigenetic processes in plants are scarce; however, this line of research needs to be exploited. The precursor of ethylene biosynthesis, SAM, is the donor of methyl groups for DNA methylation $[65,66]$, and ethylene signaling seems to be linked to chromatin regulation by histone modifications directly mediated via EIN2 [67]. In animal cells [68], the levels of metabolic substrates such as SAM and S-adenosylhomocysteine (SAH), the derived compound resulting from the transfer of the methyl group of SAM to a donor, change the expression of genes related to the growth and health. In plants [69], ethylene can be an extra player in this balance since the pool of SAM controls ethylene production. For instance, the knockdown of SAMS genes in rice, characterized by a decrease of SAM synthesis and consequently ethylene production, showed a great reduction in DNA and histone methylation, leading to a delayed germination, reduced fertility, and late flowering [70]. The role of epigenetic modifications on plant regeneration efficiency, with dynamic changes in chromatin structure leading to callus formation has been recognized [71]. Recent studies reported a direct role of the positive regulator of ethylene signaling, EIN2-C, in histone acetylation [72-75]. EIN2-C seems to be involved in the recruitment of an unknown histone acetyltransferase (HAT) and simultaneously in the inhibition of histone deacetylases (HDAs) activity, leading to acetylation of specific histone residues and subsequent EIN3-dependent transcriptional activation [67]. Overall, ethylene and/or its modulation may affect the activity of important enzymes linked to epigenetic modifications, such as methyltransferases, which catalyze methylation of a large spectra of substrates such as DNA and RNA, and HATs and HDAs, linked to histone modifications. Thus, modifying transcription and translation processes and the subsequent control of mechanisms such as plant growth and responses to biotic and abiotic stresses [76].

\section{Ethylene Integration in Hormone and Stress-Induced In Vitro Plant Regeneration}

Plant regeneration depends on cellular plasticity, i.e., the ability of cells to assume different differentiation pathways, ending in different cellular fates [3]. The regeneration capacity differs from species to species and, within the same species, different explants can show different response to regeneration [77]. Juvenile explants, such as young leaves, or immature zygotic embryos, generally have high generation capacity [3]. In vitro plant regeneration can occur directly from explant or indirectly through a preinduced pluripotent mass of cells, denominated callus [4]. A balance between auxins and cytokinins has a fundamental role in promoting organogenesis, inducing callus formation and subsequent shoot development [78-80]. SE is mainly triggered by auxins and by stress factors, such as osmotic and/or oxidative stress, leading to acquisition of embryogenic competence [81,82]. The crosstalk between ethylene with auxins and cytokinins has been progressively unveiled. In a brief overview, Swarup et al. [83] have reported an increase in the rate of the endogenous auxin synthesis, IAA, in Arabidopsis seedlings in response to 10 and $100 \mu \mathrm{M}$ ACC. A decrease in IAA content in the presence of $10 \mu \mathrm{M}$ AVG was also observed, suggesting that ethylene upregulates auxin biosynthesis. However, note that AVG itself can also reduce IAA biosynthesis by inhibition of tryptophan aminotransferase as already mentioned [27]. 
In Arabidopsis roots, an increase of IAA concentration in the presence of ACC $(100 \mu \mathrm{M})$ and a decrease of IAA synthesis rate at $10 \mu \mathrm{M}$ AVG have also been reported [84]. A reduction in free IAA content in the roots of the ethylene-overproducer mutant eto1-1 was reported, which was also found, to lesser extent, when wild-type Arabidopsis was submitted to $1 \mu \mathrm{M}$ ACC [85]. Furthermore, a recent work [86] showed also lower levels of free IAA in the same mutant, due to a downregulation of key auxin biosynthetic genes. Ethylene seems also to regulate auxin transport. ACC $(1 \mu \mathrm{M})$ treatments increased the expression of PINFORMED3 (PIN3) and PIN7 auxin efflux carriers in Arabidopsis roots while AVG $(1 \mu \mathrm{M})$ reduced this expression, leading to an inhibition of lateral root formation/growth since it prevents localized auxin accumulation in the lateral root-forming zone [85]. Moreover, in Arabidopsis seedlings, ethylene treatments increased AUX1 influx carrier expression with auxin accumulation at the apical hook. In addition, an increase in auxin biosynthesis at the inner side of the hook was reported, leading to an enhanced curvature [87]. Overall, ethylene seems to modulate auxin transport/distribution through PINs and AUX1 transporters (see [88] for a detailed crosstalk). Regarding auxin's effect in ethylene biosynthesis, exogenous IAA treatment $(20 \mu \mathrm{M})$ applied to Arabidopsis seedlings enhanced the constitutive expression of diverse ACS gene family members in roots [89]. ACS1 and ACS2 genes were also upregulated in the presence of 50 and $100 \mu \mathrm{M}$ IAA in watermelon leaves [90]. Concerning cytokinins, Arabidopsis seedlings treated with $5 \mu \mathrm{M}$ of the synthetic cytokinin, benzyladenine (BA), showed a higher ethylene production due to the stabilization of ACS5 isoform [53]. Similarly, it was found that BA treatments increase the stability of ACS5 and ACS9 isoforms in Arabidopsis [91], suggesting that cytokinin acts post-transcriptionally, leading to ACS stabilization and a subsequent increase in ethylene production. Ethylene seems also to increase the levels of cytokinins modulated by an upregulation of key cytokinin biosynthetic genes, as reported in the Arabidopsis mutant eto1-1 [86].

Apart from the role of plant hormones in regeneration, wounding-initially applied to explants-seems to be essential to initiate both regeneration processes [3]. Wounding triggers stress responses, inducing transcriptional changes with marked changes in metabolism and protein synthesis. In turn, inherent regulators of the cell cycle are activated, leading to cell proliferation and consequent callus formation [92]. Wounding is also crucial to increase the levels of SE responsiveness in the leaves of Solanum betaceum [93] and Arbutus unedo [94]. Interestingly, ethylene biosynthesis seems to be stimulated by wounding in several plant tissues [95-98]. Wounding seems to enhance ACS activity over time after cutting, leading to a greater ACC synthesis and consequently increases ethylene production [95]. This increase seems to be in agreement with the role of ethylene in several stress responses, since its role in both biotic [99-101] and abiotic [102,103] stresses has been recognized. Furthermore, wounding also promotes an accumulation of cytokinins at cutting sites leading to callus formation [92], which can also be related to the increase in ethylene biosynthesis [53,91].

As the success of regeneration processes highly depends on hormonal and stress induction, the influence of ethylene in key regeneration hormones, such as auxins and cytokinins, and in stress responses, should be markedly considered. 


\section{Influence of Ethylene Modulation in Regeneration Processes}

The influence of ethylene in in vitro processes started to be studied more deeply in the last years of the 20th century, with relevant reviews published by Biddington [5] and Kumar et al. [104]. More recently, numerous studies have been carried out regarding regenerating processes, such as axillary meristem culture, organogenesis, and SE. In the next sections an overview of those studies will be presented and discussed in order to elucidate the effect of this hormone in in vitro regeneration. Detailed summaries of several studies using chemical modulators or using mutants and transgenic lines are presented in Tables 1 and 2, respectively.

\subsection{Organogenesis}

Ethylene modulation seems to have different impacts in the organogenesis process, depending on the species. In gloxinia, inhibiting ethylene perception using silver thiosulfate, increased the number of shoots per leaf explants [105]. Furthermore, inhibition of ethylene biosynthetic enzymes, with AVG $(6.24 \mu \mathrm{M})$ and cobalt chloride $(7.7 \mu \mathrm{M})$, also increased the number of shoots per explant, albeit to a lesser degree when compared to silver thiosulfate treatments. However, at 62.43 and $124.87 \mu \mathrm{M}$ AVG or 77 and $154 \mu \mathrm{M} \mathrm{CoCl}_{2}$, both chemicals showed a negative impact on regeneration. Inhibition of ethylene perception seems also to positively affect shoot regeneration from cotyledons in melon [106]. Regeneration capacity has increased by about twofold using 60 or $120 \mu \mathrm{M}$ of silver nitrate. In turn, shoot regeneration capacity decreased in the presence of 69.2 and $138.4 \mu \mathrm{M}$ ETH treatments, where ethylene production was significantly higher compared to both control and silver nitrate treatments. In agreement, using the leaves and cotyledons of a melon transgenic line (Table 2), expressing antisense ACO, greatly increased shoot regeneration [107]. Leaves and cotyledons show a 3.5- and 2.8-fold increase in regeneration capacity when compared to wild-type, respectively. Despite a great decrease of ACO activity in both transgenic explants, cotyledons showed a higher ethylene production compared with leaves, which can justify the differences observed in the regeneration response of both transgenic explants [107]. Explants of wild-type or transgenic lines treated with ETH showed a highly decrease in regeneration capacity and, at the higher ETH concentration $(100 \mu \mathrm{M})$ a complete inhibition of regeneration was reported. A considerable increase of shoot regeneration capacity from hypocotyls of mustard in the presence of $17.66 \mu \mathrm{M}$ silver nitrate was also detected [108]. Also in mustard, both ethylene inhibitors AVG and silver nitrate enhanced the shoot regeneration in leaf discs and petioles [109], whereas combined treatments with ethylene inhibitors and ETH decreased the regeneration capacity in leaf explants. Pretreated leaf explants with silver nitrate also showed a decrease in shoot regeneration capacity in further organogenesis induction with silver nitrate. However, shoot regeneration capacity of the same explants was not affected in control or in AVG treatments [109]. 


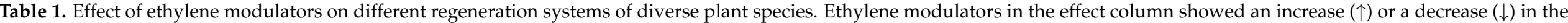
respective parameter when compared to control.

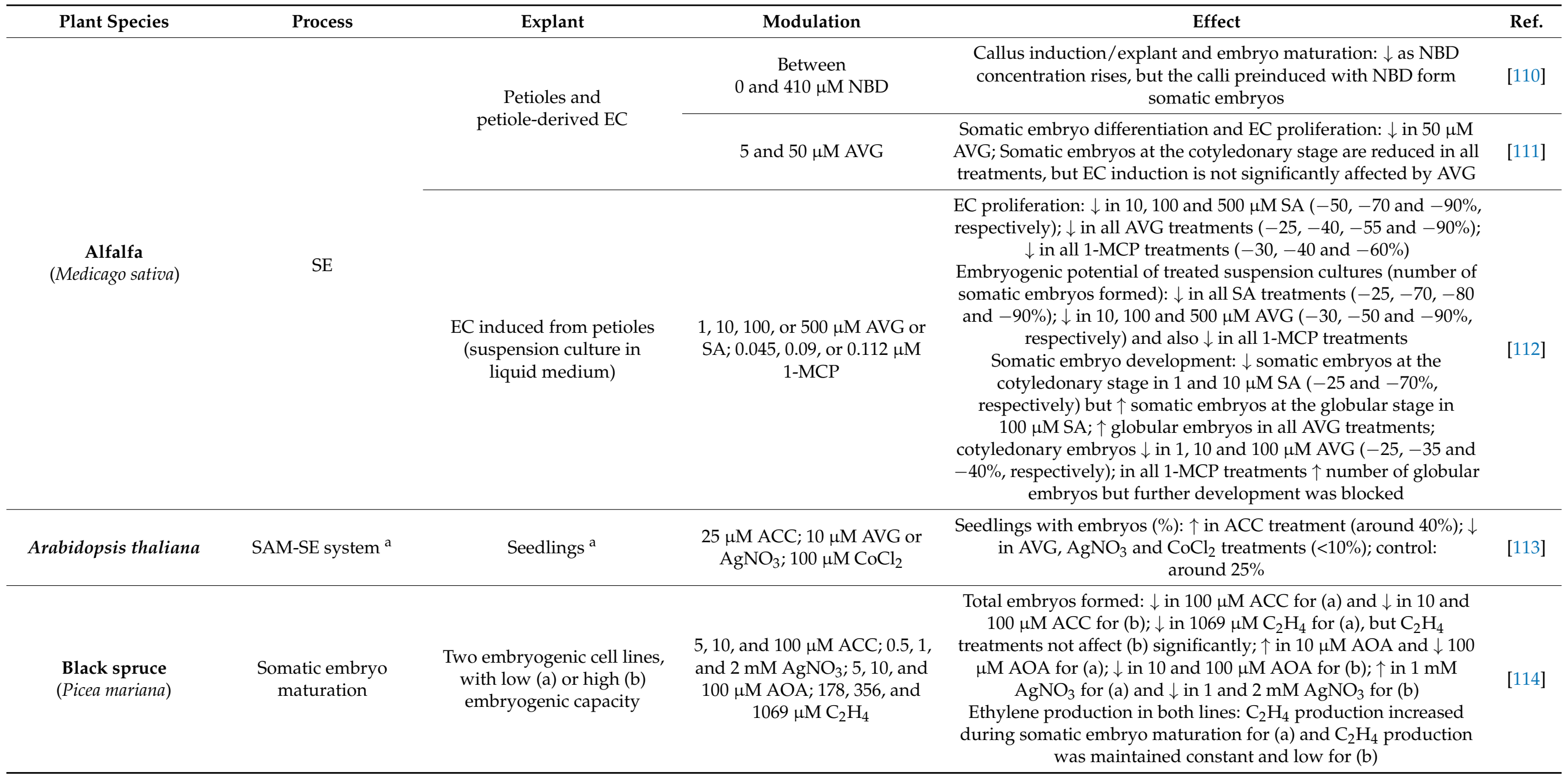


Table 1. Cont.

\begin{tabular}{|c|c|c|c|c|c|}
\hline Plant Species & Process & Explant & Modulation & Effect & Ref. \\
\hline $\begin{array}{c}\text { Carrot } \\
\text { (Daucus carota) }\end{array}$ & SE & $\begin{array}{l}\text { Embryogenic cell suspension } \\
\text { induced from hypocotyls }\end{array}$ & $\begin{array}{c}10,20,50, \text { and } 100 \mu \mathrm{M} \mathrm{CoC1}{ }_{2} \\
69.2 \text { and } 692 \mu \mathrm{M} \mathrm{ETH}\end{array}$ & $\begin{array}{l}\text { Number somatic embryos formed (No./mL of cell suspension): } \uparrow \\
\text { in } 10,20 \text { and } 50 \mu \mathrm{M} \mathrm{CoC1} 1_{2} \text {, but } \downarrow \text { in } 100 \mu \mathrm{M} \text { (best treatment, } \\
79 \text { No. } / \mathrm{mL} \text { at } 50 \mu \mathrm{M} \text {; control: } 23 \text { No. } / \mathrm{mL} \text { ); } \downarrow \text { in both ETH } \\
\text { treatments; } \downarrow \text { in } 50 \mu \mathrm{M} \mathrm{CoC} 1_{2}+69.2 \text { or } 692 \mu \mathrm{M} \text { ETH }\end{array}$ & [115] \\
\hline $\begin{array}{c}\text { Gloxinia } \\
\text { (Sinningia speciosa) }\end{array}$ & Org ${ }^{b}$ & Leaf explants & $\begin{array}{c}6.24,31.22,62.43, \text { and } \\
124.87 \mu \mathrm{M} \text { AVG; } 7.7,38.5,77 \\
\text { and } 154 \mu \mathrm{M} \mathrm{CoCl} l_{2} ; 3,15.25 \\
30.5, \text { and } 61 \mu \mathrm{M} \text { STS }\end{array}$ & $\begin{array}{c}\text { Regeneration (\%) and shoots per explant: } \uparrow \text { in } 15.25 \text { and } 30.5 \mu \mathrm{M} \\
\text { STS (best treatment, } 15.25 \mu \mathrm{M} \text { STS, } 40 \% \text { more shoots/explant); } \uparrow \text { in } \\
6.24 \mu \mathrm{M} \text { AVG or } 7.7 \mu \mathrm{M} \mathrm{CoCl} l_{2} \text { and } \downarrow \text { in } 62.43 \text { and } 124.87 \mu \mathrm{M} \text { AVG } \\
\text { or } 77 \text { and } 154 \mu \mathrm{M} \mathrm{CoCl}_{2}\end{array}$ & [105] \\
\hline $\begin{array}{l}\text { Lemon } \\
\text { (Citrus limon) }\end{array}$ & Org & $\begin{array}{l}\text { Adult nodal segments } \\
\text { from two cultivars (a) Verna } \\
51 \text { and (b) Fino } 49\end{array}$ & $\begin{array}{l}10,20 \text {, and } 30 \mu \mathrm{M} \text { ACC, } \\
\mathrm{CoCl}_{2} \text { or STS; } 5,10 \text {, and } \\
20 \mu \mathrm{M} \mathrm{ETH}\end{array}$ & $\begin{array}{l}\text { Regeneration (\%): } \downarrow \text { in } 10,20 \text { and } 30 \mu \mathrm{M} \mathrm{ACC} \text { for both; } \downarrow \text { in } 10 \text { and } \\
20 \mu \mathrm{M} \mathrm{ETH} \mathrm{for} \mathrm{(b);} \uparrow \text { in } 10 \text { and } 20 \mu \mathrm{M} \mathrm{STS} \text { for both; } \downarrow \text { in } 10 \text { and } \\
20 \mu \mathrm{M} \mathrm{CoCl} \mathrm{l}_{2} \text { for (b) and } \downarrow 30 \mu \mathrm{M} \mathrm{CoCl} l_{2} \text { for both } \\
\text { Buds per explant: } \downarrow \text { in } 10,20 \text { and } 30 \mu \mathrm{M} \text { ACC for both and } \downarrow \text { in } \\
\qquad 30 \mu \mathrm{M} \mathrm{CoCl} l_{2} \text { for (a) }\end{array}$ & [116] \\
\hline $\begin{array}{l}\text { Yellow passionfruit } \\
\text { (Passiflora edulis) }\end{array}$ & Axillary bud culture & Nodal segments & $\begin{array}{l}3 \text { and } 10 \mu \mathrm{M} \text { ACC, STS, } \\
\text { or AVG }\end{array}$ & $\begin{array}{c}\text { Buds and leaf area per explant: } \downarrow \text { in } 3 \text { and } 10 \mu \mathrm{M} \text { ACC and } \uparrow \text { in } 3 \\
\text { and } 10 \mu \mathrm{M} \text { STS or AVG treatments } \\
\text { Shoot length per explant: } \downarrow \text { in } 3 \text { and } 10 \mu \mathrm{M} \text { ACC treatments }\end{array}$ & [117] \\
\hline $\begin{array}{c}\text { Melon } \\
\text { (Cucumis melo) }\end{array}$ & Org & Cotyledons ${ }^{b}$ & $\begin{array}{l}60 \text { or } 120 \mu \mathrm{M} \mathrm{AgNO} \\
69.2 \text { or } 138.4 \mu \mathrm{M} \mathrm{ETH}\end{array}$ & $\begin{array}{l}\text { Shoot regeneration (\%): } \uparrow \text { in all } \mathrm{AgNO}_{3} \text { treatment for all genotypes; } \\
\text { line with best shoot regeneration, } 75 \% \text { at } 60 \mu \mathrm{M} \text { and } 68 \% \text { at } 120 \mu \mathrm{M} \\
\text { (control } 35 \%) \\
\text { Shoot regeneration (\%) for the best line: } \downarrow \text { in both ETH treatments } \\
(19 \% \text { and } 10 \% \text { at } 69.2 \mu \mathrm{M} \text { and } 138.4 \mu \mathrm{M} \text { ETH, respectively) }\end{array}$ & [106] \\
\hline \multirow{3}{*}{$\begin{array}{c}\text { Mustard } \\
\text { (Brassica juncea L.) }\end{array}$} & & Hypocotyls & $17.66 \mu \mathrm{M} \mathrm{AgNO} 3$ & $\begin{array}{l}\text { Shoot regeneration (\%): } \uparrow \text { in } \mathrm{AgNO}_{3} \text { treatment with } 95.89 \% \text { shoot } \\
\text { regeneration (control: } 14.6 \% \text { ) }\end{array}$ & [108] \\
\hline & Org & Leaf disc and petioles & $\begin{array}{c}20 \mu \mathrm{M} \mathrm{AgNO} \mathrm{An}_{3} \text { and } 5 \mu \mathrm{M} \\
\mathrm{AVG} ; \mathrm{AgNO}_{3} \text { or AVG with } 10 \text {, } \\
25, \text { or } 50 \mu \mathrm{M} \mathrm{ETH} \text { (combined) }\end{array}$ & $\begin{array}{c}\text { Shoot regeneration (\%) from both explants: } \uparrow \text { in both } \mathrm{AgNO}_{3} \text { and } \\
\text { AVG treatments, with } 80-90 \% \text { (control: } 20-30 \%) \\
\text { Shoot regeneration (\%) in combined treatments (leaf explants): } \downarrow \text { in } \\
25 \text { or } 50 \mu \mathrm{M} \text { ETH }+ \text { AVG ( } 50 \mu \mathrm{M} \text { ETH }+ \text { AVG almost inhibited } \\
\left.\text { regeneration and slight } \downarrow \text { in ETH }+\mathrm{AgNO}_{3}\right)\end{array}$ & \multirow[t]{2}{*}{ [109] } \\
\hline & Plant growth & Shoots & $\begin{array}{c}20 \mu \mathrm{M} \mathrm{AgNO}, 5 \mu \mathrm{M} \text { AVG, or } \\
50 \mu \mathrm{M} \text { ETH }\end{array}$ & $\begin{array}{c}\text { Plant growth parameters, such as plant height, number of leaves, } \\
\text { number of roots and root length: } \downarrow \text { in both } \mathrm{AgNO}_{3} \text { and ETH } \\
\text { treatments (AVG does not have a very significant effect on the } \\
\text { same parameters) }\end{array}$ & \\
\hline
\end{tabular}


Table 1. Cont.

\begin{tabular}{|c|c|c|c|c|c|}
\hline Plant Species & Process & Explant & Modulation & Effect & Ref. \\
\hline $\begin{array}{c}\text { Poplar } \\
\text { (Populus tremula) }\end{array}$ & Org & Nodal segments & $\begin{array}{c}5,10, \text { and } 15 \mu \mathrm{M} \text { AVG; } 0.5,1 \\
\text { and } 5 \mu \mathrm{M} \mathrm{ACC} ; 5 \text { and } \\
10 \mu \mathrm{M} \text { ETH }\end{array}$ & $\begin{array}{l}\text { Shoot elongation and number of buds and roots/explant: } \downarrow \text { in } \\
10-15 \mu \mathrm{M} \text { AVG, } \uparrow \text { in } 5 \mu \mathrm{M} \text { ACC and } \uparrow \text { in } 10 \mu \mathrm{M} \text { ETH }\end{array}$ & [118] \\
\hline $\begin{array}{l}\text { Robusta coffee } \\
\text { (Coffea canephora) }\end{array}$ & SE & $\begin{array}{c}\text { EC developed from } \\
\text { hypocotyl and leaf explants }\end{array}$ & $\begin{array}{c}20 \text { and } 40 \mu \mathrm{M} \mathrm{AgNO}{ }_{3}, \mathrm{CoCl}_{2}, \\
\text { or SA }\end{array}$ & $\begin{array}{l}\text { Calli responded for embryogenesis (\%): } \uparrow \text { in all } \mathrm{AgNO}_{3} \text { treatments } \\
\text { (best treatment, } 40 \mu \mathrm{M}, 48 \% \text { ); } \uparrow \text { in all } \mathrm{CoCl}_{2} \text { treatments (best } \\
\text { treatment, } 40 \mu \mathrm{M}, 28 \%) ; \uparrow \text { in all SA treatments (best treatment, } \\
\qquad 40 \mu \mathrm{M}, 32 \% \text { ), control } 5 \% \\
\text { Number of somatic embryos per callus: } \uparrow \text { in both all } \mathrm{AgNO}_{3} \text { and } \\
\text { AVG treatments (best treatment, at } 40 \mu \mathrm{M}, 153 \text { and } 45 \text { embryos, } \\
\text { respectively); in all SA treatments, only pro-embryogenic nodular } \\
\text { masses appeared (control did not produce somatic embryos) }\end{array}$ & [120] \\
\hline $\begin{array}{c}\text { Soybean } \\
\text { (Glycine max) }\end{array}$ & SE & $\begin{array}{l}\text { Cotyledons from } \\
\text { cultivars with different } \\
\text { embryogenic capacity }\end{array}$ & $10 \mu \mathrm{M}$ ACC or AVG & $\begin{array}{l}\text { Somatic embryo production: } \uparrow \text { in ACC treatment for two } \\
\text { recalcitrant cultivars (slight increase, but not significantly, for } \\
\text { cultivar with high embryogenic capacity); } \downarrow \text { in AVG treatment } \\
\text { (almost inhibited) for both two recalcitrant cultivars and cultivar } \\
\text { with high embryogenic capacity }\end{array}$ & [113] \\
\hline $\begin{array}{c}\text { Spinach } \\
\text { (Spinacia oleracea) }\end{array}$ & SE & Roots & $\begin{array}{l}1,10, \text { and } 100 \mu \mathrm{M} \mathrm{ETH} \\
\text { or } \mathrm{AgNO}_{3} \\
1 \text { and } 10 \mu \mathrm{M} \text { AVG }\end{array}$ & $\begin{array}{c}\text { Embryogenic callus (\%): } \downarrow \text { in all } \mathrm{AgNO}_{3} \text { and } \mathrm{AVG} \text { treatments and } \\
\left.\uparrow \text { in } 10 \text { and } 100 \mu \mathrm{M} \mathrm{ETH} \text { (only in combination } \mathrm{w} / 0.1 \mu \mathrm{M} \mathrm{GA} \mathrm{A}_{3}\right) \\
\text { Calli forming embryos (\%): } \downarrow \text { in all ETH treatments (somatic } \\
\text { embryos formation inhibited at } 100 \mu \mathrm{M} \text { ) and } \uparrow \text { in all } \\
\mathrm{AgNO}_{3} \text { treatments } \\
\text { Number of embryos } / \text { calli: } \downarrow \text { in all ETH treatments and } \uparrow \text { in all } \\
\mathrm{AgNO}_{3} \text { treatments (best treatment, } 10 \mu \mathrm{M} \mathrm{AgNO}, \\
3 \times \text { more embryos) }\end{array}$ & [121] \\
\hline $\begin{array}{l}\text { Summer snowflake } \\
\text { (Leucojum aestivum) }\end{array}$ & SE & $\mathrm{EC}$ & $\begin{array}{c}10 \mu \mathrm{M} \mathrm{ACC}, \mathrm{AgNO}_{3}, \text { or STS } \\
\mathrm{KMnO}_{4}(4.5 \mathrm{~g} \text { solid })\end{array}$ & $\begin{array}{c}\text { EC increment (\%): } \uparrow \text { in both } \mathrm{AgNO}_{3} \text { and in } \mathrm{KMnO}_{4} ; \downarrow \text { in both ACC } \\
\text { and STS treatments } \\
\text { Somatic embryo induction and maturation: } \uparrow \text { in ACC treatment } \\
\text { Length of plantlets development: } \uparrow \text { in } \mathrm{KMnO}_{4} \text { treatment }\end{array}$ & [122] \\
\hline
\end{tabular}


Table 1. Cont.

$\begin{array}{llll}\text { Plant Species } & \text { Process } & \text { Explant } & \text { Modulation }\end{array}$

Leaves

\section{Tomato}

(Solanum pennellii and

Solanum lycopersium)

Org from two genotypes (Solanum pennellii and F1:

Solanum pennellii vs

Solanum lycopersicum

cv. Anl27)
$5.8,14.5,29$, and $58 \mu \mathrm{M}$ $\mathrm{AgNO}_{3} ; 4.2,10.5,21$, and $42 \mu \mathrm{M} \mathrm{CoCl}_{2} ; 9.8,24.5,49$, and $98 \mu \mathrm{M}$ ACC;

$6.9,17.2,34.5$, and $69 \mu \mathrm{M} \mathrm{ETH}$

\section{Effect}

Explants with buds (\%): $\downarrow$ in 14.5, 29 and $58 \mu \mathrm{M} \mathrm{AgNO} 3$ for S. pennellii; $\downarrow$ in $21 \mu \mathrm{M} \mathrm{CoCl} l_{2}$ for $\mathrm{F} 1 ; \downarrow$ in $98 \mu \mathrm{M}$ ACC for both genotypes; $\downarrow$ in 17.2, 34.5, and $69 \mu \mathrm{M}$ ETH for S. pennellii and $\downarrow$ in 34.5 and $69 \mu \mathrm{M}$ ETH for F1; (lowest percentage at $69 \mu \mathrm{M}$ ETH for

both S. pennellii and F1, with $20 \%$ and $16 \%$, respectively)

Explants with shoots (\%): $\downarrow$ in 14.5, 29 and $58 \mu \mathrm{M} \mathrm{AgNO}$ for S. pennellii; $\downarrow$ in $21 \mu \mathrm{M} \mathrm{CoCl} l_{2}$ for $\mathrm{F} 1$; $\downarrow$ in 24.5 and $98 \mu \mathrm{M}$ ACC for both $S$. pennellii and $\mathrm{F} 1 ; \downarrow$ in all ETH treatments for both genotypes (lowest percentage at $69 \mu \mathrm{M}$ ETH for both S. pennellii and F1, with

$$
12 \% \text { and } 8 \% \text {, respectively) }
$$

Nunber of shoots per explant with shoots: $\downarrow$ in all $\mathrm{AgNO}_{3}$ treatments for S. pennellii; $\uparrow$ in $9.8,49$ and $98 \mu \mathrm{M}$ ACC for $S$. pennellii $(\uparrow \times 2$ more compared to control (around 5 shoots), with around 10 shoots); $\downarrow$ in $17.2,34.5$ and $69 \mu \mathrm{M}$ ETH for S. pennellii;

(lowest number at $58 \mu \mathrm{M} \mathrm{AgNO}_{3}$ and $69 \mu \mathrm{M}$ ETH with 0.96 and 1 , respectively)

All $\mathrm{AgNO}_{3}$ treatments inhibited regeneration for $\mathrm{F} 1$

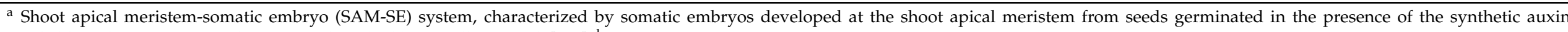
2,4-dichlorophenoxyacetic acid (2,4-D) as described by Mordhorst et al. [124]. ${ }^{\mathrm{b}}$ Org-Organogenesis. 
Furthermore, pretreated plants with AVG maintained the same regeneration capacity in posterior induction with both inhibitors. Authors suggest that mustard plants can be more sensible to Ag (I) and to its accumulation than to AVG. Actually, in the same study, further plant growth parameters were negatively affected by silver nitrate, but not by AVG treatment. Moreover, as mentioned in Section 4, mustard seedlings exposed to $\mathrm{AgNO}_{3}(1$ and $3 \mathrm{mM})$ exhibited higher levels of oxidative stress along with a reduction in photosynthesis, due to silver nitrate accumulation, also resulting in a decline of plant growth parameters [38]. Shoot regeneration from leaf discs or hypocotyl segments of transgenic lines of mustard (Table 2), expressing antisense $A C O$, was greatly enhanced compared to wild-type, as reported by Pua and Lee [125]. Shoot regeneration (\%) in these transgenic lines was similar (about $90 \%$, Table 1 ) to that reported when a chemical approach using silver nitrate and AVG was used [108,109]. In lemon, ACC and ETH treatments seems to decrease shoot regeneration in adult nodal segments, while silver thiosulfate treatments enhanced it [116]. Induced organogenesis in leaves of two genotypes of tomato (Solanum pennellii and F1: Solanum pennellii vs Solanum lycopersicum cv. Anl27; Table 1) revealed that an excessive amount of ETH or ACC negatively affected the percentage of explants showing buds in both genotypes, whereas lower concentrations of both ethylene precursors had no relevant effect [123]. Silver nitrate also negatively affected the number of explants with buds in Solanum pennellii and, interestingly, completely inhibited regeneration from F1 explants. Cobalt chloride decreased this percentage from F1 explants at only $21 \mu \mathrm{M}$, but it did not affect Solanum pennellii. ETH treatments showed a decrease regarding explants with shoots (\%) for both genotypes similarly to silver nitrate treatments in Solanum pennellii. Although the negative effect of both ETH and silver nitrate in the number of shoots per explant with shoots (\%) in Solanum pennellii, ACC treatments enhanced this parameter. These results show that different genotypes have different responses and sensitivity to ethylene and/or its modulation, affecting its regeneration capacity.

In poplar (Table 1), ethylene precursors ACC $(5 \mu \mathrm{M})$ and ETH $(10 \mu \mathrm{M})$ positively affect regeneration and subsequent plant development and growth, in parameters such as shoot elongation, induction and development of buds, and also root formation per explant [118]. On the other hand, AVG treatments in a range of 10-15 $\mu \mathrm{M}$ negatively affected these parameters. Experiments carried out during shoot regeneration in cotyledons of different Arabidopsis mutants (Table 2) showed that shoot regeneration decreased in ethylene insensitive mutants etr1-1 and ein2-1, whereas it increased in ethylene constitutive response mutants ctr1-1 and ctr1-12, and also in ethylene overproducer mutant eto1-1, suggesting a positive role for ethylene on Arabidopsis organogenesis [126].

\subsection{Somatic Embryogenesis}

The first studies of the SE process in carrot (Table 1) showed that inhibition of ACO, using cobalt chloride, increased the number of somatic embryos formed from embryogenic cell suspensions [115]. Furthermore, ethylene measurements confirmed that the number of somatic embryos increased with the decrease of ethylene production. The negative effect of ethylene in carrot SE was further confirmed with ETH treatments (69.2 and $692 \mu \mathrm{M})$, in which the number of somatic embryos formed decreased [115]. In robusta coffee [119], the development of somatic embryos from leaf explants of two genotypes greatly increased in the presence of silver nitrate treatments $(30$ and $60 \mu \mathrm{M})$. In this species, high silver nitrate concentrations ( 150 and $300 \mu \mathrm{M})$ reduced somatic embryo formation, perhaps, due to its toxicity to plant tissues, rather than due to an inhibitory effect on ethylene perception [119]. Interestingly, the two different genotypes showed a similar great yield in somatic embryo formation (around $+60 \%$ ) but at different silver nitrate concentrations, one at 30 and the other at $60 \mu \mathrm{M}$, suggesting different sensitivities to ethylene according to the genotype. The effect of ethylene modulators on somatic embryo development from embryogenic calli in robusta coffee was also analyzed [120]. The data showed that somatic embryo development was poor in the control (with no modulators used), whereas in the presence of silver nitrate, cobalt chloride, or salicylic acid, this recalcitrance seemed to be reversed and an increase 
in somatic embryo formation was observed. However, results showing a positive effect of ethylene on direct SE from leaf explants of the same species were also reported [127]. SE was directly induced in leaf explants by cytokinin in both the Fuentes et al. [119] and Hatanaka et al. [127] studies. However, a preculture of 5 days of leaf explants in induction medium without silver nitrate was carried out in the work of Fuentes et al. [119]. This can somehow explain the differences observed, suggesting that ethylene can be necessary in an initial phase to promote embryogenic competence in leaf explants, but later disrupt somatic embryo development [119]. This could justify why an initial ethylene inhibition disrupted direct SE from leaf explants [127], but its later inhibition did not affect somatic embryo development [119].

Preliminary studies carried out in our lab with a solanaceous tree species (Solanum betaceum; commonly known as tamarillo), showed that at the induction stage, the leaf explants exposed to AgNO3 and AVG only produced non-embryogenic calli, whereas ETH significantly increased the induction of embryogenic tissue [128]. Furthermore, ETH treatments accelerated the induction of embryogenic calli. During somatic embryo development, following embryogenic callus transfer to an auxin-free medium, the treatment with AgNO3 and AVG enhanced the number of somatic embryos developed from embryogenic calli, whereas the presence of ETH blocked development beyond the globular stage. Moreover, as found in other species, ethylene may be involved at different steps of $\mathrm{SE}$ induction of tamarillo, from induction to embryo development. These results indicate that ethylene certainly has a role during somatic embryo formation and development in $S$. betaceum, but further studies are necessary to clarify how this hormone interacts with other players that are also crucial for somatic embryo formation in this species, such as auxins and high sucrose levels [93]. 


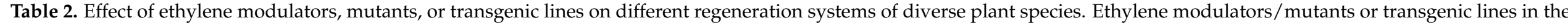
effect column showed an increase $(\uparrow)$ or a decrease $(\downarrow)$ in the respective parameter when compared to control.

\begin{tabular}{|c|c|c|c|c|c|}
\hline Plant Species & Process & Type of Explant & Modulation & Effect & Ref. \\
\hline \multirow{2}{*}{ Arabidopsis thaliana } & Org $^{a}$ & Cotyledons & Ethylene mutants & $\begin{array}{l}\text { Shoot regeneration (\%): } \downarrow \text { in ethylene insensitive mutants (etr1-1 } \\
\text { and ein2-1), } \uparrow \text { in ethylene constitutive response mutants (ctr1-1 and } \\
\text { ctr1-12) and } \uparrow \text { in ethylene overproduction mutant (eto1- } 1 \text { ) }\end{array}$ & {$[126]$} \\
\hline & SE & Immature zygotic embryos & $\begin{array}{c}1,5,10 \mu \mathrm{M} \mathrm{ACC} ; 1,10 \mu \mathrm{M} \\
\mathrm{CoCl}_{2} ; 1,10,15 \mu \mathrm{M} \mathrm{AVG} ; 1 \\
10,100 \mu \mathrm{M} \mathrm{AgNO} \text { or } \\
250 \mathrm{mM} \mathrm{KMnO}_{4} ; \\
\text { ethylene mutants }\end{array}$ & 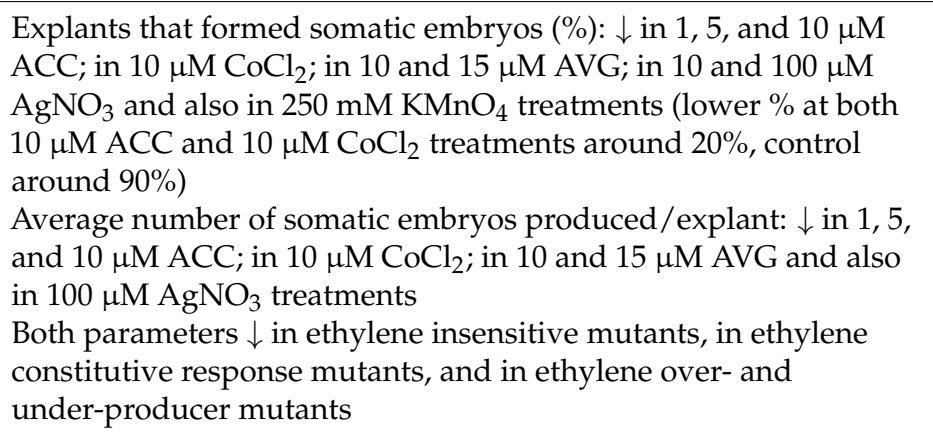 & {$[130]$} \\
\hline Medicago truncatula & $\mathrm{SE}$ & $\begin{array}{l}\text { Two different genotype } \\
\text { leaf-derived EC lines, with } \\
\text { different embryo } \\
\text { production capability }\end{array}$ & $\begin{array}{c}\text { 0.1, } 1,10 \text {, and } 100 \mu \mathrm{M} \text { ACC, } \\
\text { MGBG, } \mathrm{AgNO}_{3} \text {, or AVG; } \\
A C S \text { and } A C O \text { expression; } \\
\text { MtSERF } 1^{\mathrm{b}} \text { knockdown } \\
\text { (using RNAi) }\end{array}$ & $\begin{array}{l}\text { Number of somatic embryos developed/explant: } \uparrow \text { in } 1 \text { and } 10 \mu \mathrm{M} \\
\mathrm{ACC} \text { and in } 10 \text { and } 100 \mu \mathrm{M} \text { MGBG, best treatments } 10 \mu \mathrm{M} \text { ACC } \\
\text { and } 100 \mu \mathrm{M} \mathrm{MGBG},=\text { around } 35 \text { embryos/explant (control = } \\
\text { around } 12) ; \downarrow \text { in } 1 \text { and } 10 \mu \mathrm{M} \text { AVG or } \mathrm{AgNO}_{3} \text { and completely } \\
\text { inhibited at both } 100 \mu \mathrm{M} \text { AVG and } \mathrm{AgNO}_{3} \text { treatments; } \\
\text { ACS and ACO expression: } \uparrow \text { in line with highly embryo } \\
\text { production capacity; } \\
\text { MtSERF1 knockdown: Disrupt somatic embryo production }\end{array}$ & {$[131]$} \\
\hline
\end{tabular}


Table 2. Cont.

$\begin{array}{llll}\text { Plant Species } & \text { Process } & \text { Type of Explant } & \text { Modulation }\end{array}$

Effect

\section{Plant Species}

Melon

(Cucumis melo)

Org

Leaves and cotyledons
Transgenic plant line expressing antisense $A C O ; 50$ or $100 \mu \mathrm{M} \mathrm{ETH}$

Shoot regeneration (\%) from leaf explants: $\uparrow$ in transgenic line with $53 \%$ (control 15\%)

Shoot regeneration (\%) from cotyledon explants: $\uparrow$ in transgenic line with 37\% (control 13\%)

Shoot regeneration (\%) from both explants in response to ETH: $\downarrow$ in all ETH treatments (for both explants); transgenic leaf explants + $50 \mu \mathrm{M}$ ETH treatment shows 5\% shoot regeneration and $+100 \mu \mathrm{M}$ ETH treatment regeneration was inhibited; transgenic cotyledon explants $+50 \mu \mathrm{M}$ ETH treatment shows $8 \%$ shoot regeneration and $+100 \mu \mathrm{M}$ ETH treatment shows $1 \%$

Shoot regeneration (\%) from leaf explants: $\uparrow$ in 9 transgenic lines, between $58 \%$ and $92 \%$ (control $12-16 \%$ ), 4 best lines \%

$(83,79,80,92)$;

10 transgenic plant lines

\section{Mustard}

(Brassica juncea)

Org
Leaf discs

and

Hypocotyl segments expressing antisense $A C O$;

$5 \mu \mathrm{M}$ AVG, $10 \mu \mathrm{M} \mathrm{AgNO}$, or

$50 \mu \mathrm{M}$ ETH (alone or combined)

Shoot regeneration (\%) from leaf explants in response to inhibitors and/or ETH: $\uparrow$ in WT plants $+\mathrm{AVG}$ or $+\mathrm{AgNO}_{3}$ treatments

(similar \% compared with the 4 transgenic lines w/o treatment),

(WT plants $+\mathrm{AgNO}_{3}+\mathrm{ETH}=$ around $60 \%$ ); Both WT plants +

AVG + ETH $(\%)$ and the 4 transgenic lines + ETH (\%) are similar to control;

Shoot regeneration (\%) from hypocotyl explants: $\uparrow$ in the 4 best transgenic lines, $85-95 \%$ (control = around 5\%)

Leaf area/explant: $\uparrow$ in both (a) $+\mathrm{AgNO}_{3}$ and (b) $+\mathrm{AgNO}_{3} ; \uparrow$ in

Different ventilations:

(a) sealed with silicone rubber bungs; (b) capped with

Potato

Plant growth: Callus formation
Nodal segments with unfolded leaf 
Table 2. Cont.

Plant Species Process Type of Explant

Embryogenic cell line

Scots pine

(Pinus sylvestris)
SE

embryogenetic capacity cultures with distinct

\section{Effect}

Ref.

ACS1 transcript is accumulated throughout the lines with different

embryogenic capacity and also in somatic embryos, similarly;

ACS2 transcript is accumulated only in somatic embryos (the

ACS1 and ACS2 expression ethylene production is only greatly detected in somatic embryos);

and ethylene production

$\uparrow$ ACS2 gene expression levels in the cell line with higher

during different SE stages

embryogenic capacity; embryos at cotyledonary stage showed

highly ethylene production and during germination into plantlets

ethylene production is greatly reduced

a Organogenesis. ${ }^{\mathrm{b}}$ SOMATIC EMBRYO RELATED FACTOR1 (SERF1), the expression of which is dependent on ethylene biosynthesis and perception. [131]. 
In black spruce (Table 1), a gymnosperm, the effect of inhibitors of ethylene biosynthesis and perception, AOA and silver nitrate, and also of ACC and pure ethylene on somatic embryo maturation from two cell lines with different embryogenic capacity was analyzed [114]. Inhibiting ACS activity with $10 \mu \mathrm{M}$ AOA increased the total number of somatic embryos developed from a cell line with low embryogenic capacity. However, with the same AOA treatment, a decrease in the number of somatic embryos developed from a high embryogenic cell line was observed. Similar results were reported for both lines when treated with silver nitrate. Adding pure exogenous ethylene $(1069 \mu \mathrm{M})$ along with $10 \mu \mathrm{M}$ AOA treatments reverted the previous effect of AOA observed in both cell lines, confirming that somatic embryo formation in this species is somehow regulated by ethylene. Nevertheless, higher AOA concentration $(100 \mu \mathrm{M})$ has a negative impact in somatic embryo formation on both lines. When using the ethylene precursor ACC, the formation of somatic embryos decreased at $100 \mu \mathrm{M}$ for both cell lines, and $10 \mu \mathrm{M}$ also negatively affected this parameter, although only for the high embryogenic line. Exogenous treatments with pure ethylene at $1069 \mu \mathrm{M}$ also decreased the number of somatic embryos for the low embryogenic line, without affecting significantly the line with high embryogenic capacity. The differences in embryogenic capacity seem to be related to differences in ethylene production in both cell lines. While in high embryogenic cell lines, ethylene production remains constant and low, at a supposedly optimal concentration low embryogenic cell lines have a higher ethylene production, showing a supposedly supraoptimal ethylene concentration [114]. Therefore, in this species, ethylene below or above an optimal concentration seems to be directly correlated with low embryogenic regeneration capacity.

In Scots pine [133], the expression of ACS1 and ACS2 genes during different SE stages in cell lines with different embryogenic capacity was studied (Table 2). Although the ACS1 gene was similarly expressed throughout the different lines and in different SE developmental stages, the ACS2 gene was markedly expressed only in somatic embryos, along with high ethylene production. The line with the higher embryogenic capacity showed a positive correlation between the number of somatic embryos developed, ethylene production and ACS2 expression. Ethylene production increased throughout somatic embryo development, was greatly detected at the cotyledonary stage, and decreased during subsequent somatic embryo conversion and germination [133].

In spinach (Table 1), SE was induced from root explants using inhibitors of ethylene biosynthesis and signaling — silver nitrate and AVG—and also ETH. A decreased induction of embryogenic calli from spinach roots was observed in silver nitrate and AVG treatments, while using ETH, at 10 and $100 \mu \mathrm{M}$, significantly enhanced the percentage of embryogenic calli induced [121]. However, during somatic embryo formation, ETH negatively affected the number of somatic embryos produced per explant, whereas inhibiting ethylene perception with silver nitrate greatly increased the number of somatic embryos developed per callus, the highest being a threefold increase (at $10 \mu \mathrm{M})$ when compared with the control. Once again, the results show that the effect of ethylene depends on the stage of somatic embryo differentiation.

Inhibition of ethylene perception in summer snowflake (Table 1) by silver nitrate or using potassium permanganate, as an ethylene absorbent, increased the proliferation of embryogenic calli [122]. However, this proliferation was negatively affected by silver thiosulfate. Despite the negative impact of ACC on the embryogenic calli proliferation, an increase in the number of somatic embryos formed and their posterior maturation was reported in ACC treatment. A great number of somatic embryos at torpedo stage in the presence of ACC was observed, when compared with both the control and other treatments, suggesting that ethylene is essential for somatic embryo development in Leucojum aestivum. 
Assays in Arabidopsis (Table 2) to evaluate the effect of ACC and ethylene mutants in somatic embryo formation from embryogenic calli [129] showed that as ACC concentration rose, the number of somatic embryos formed per embryogenic callus decreased. A similar effect was observed in both the ethylene overproducer mutant, eto1-1, and the ethylene constitutive response mutant, ctr1-1. Along these results, embryogenic calli treated with ACC $(200 \mu \mathrm{M})$ or from the mutants eto1-1 and ctr1-1 showed a downregulation in YUCCA genes expression. YUCCA genes are known to encode for the key enzymes of auxin biosynthesis [134] and their requirement to induce SE in Arabidopsis from embryogenic calli is known [129]. Furthermore, ACC $(200 \mu \mathrm{M})$ and the mutant eto1-1 showed a disruption in local auxin biosynthesis and consequent distribution [124]. In fact, the quadruple mutants yuc1, yuc4, yuc10, and yuc11, which impair local auxin distribution, also showed a reduction in the number of somatic embryos formed from embryogenic calli, similar to what was observed in ACC treatments at $200 \mu \mathrm{M}$. Taken together, these results provided evidence of the hormonal regulation required to induce somatic embryos in Arabidopsis' embryogenic tissue, suggesting that ethylene negatively affects SE in this species through inhibition of auxin biosynthesis and its local distribution [129]. Moreover, somatic embryo initiation in auxin-rich medium and in auxin-free medium were compared [129]. Exogenous auxin stimulated ethylene production, and its removal from the medium enhanced somatic embryo initiation along with lower levels of ethylene. Using immature zygotic embryos as explants [130], at first glance, the ethylene effect is not so clear when only ethylene modulators are used, since both ACC and silver nitrate negatively affected the SE process. In other words, SE efficiency (i.e., the percentage of explants that formed embryos) and SE productivity (i.e., the average of somatic embryos produced per explant) decreased in the presence of ETH, but also decreased in the presence of inhibitors of ethylene biosynthesis and perception (see Table 2 for more details). However, AVG and cobalt chloride at low concentration $(1 \mu \mathrm{M})$ do not affect these parameters. Using ethylene mutants, with different and opposite phenotypes, a decrease in the SE efficiency and productivity was also observed, similarly to what was observed with the chemical modulation. Taking these results into account, and knowing that in control conditions SE efficiency reaches $90 \%$, it can be concluded that immature zygotic embryos have per se an optimal ethylene production at the induction conditions, which includes $5 \mu \mathrm{M}$ 2,4-D and 20 g. $\mathrm{L}^{-1}$ sucrose [130], promoting an efficient SE process. Furthermore, in this work, the authors also studied the effect of the ETHYLENE RESPONSE FACTOR022 (ERF022) gene on Arabidopsis SE. ERF022 is a member of the ethylene response factor (ERF) family genes, which are associated with plant responses to stress [135]. It was also found that a strong inhibition of the ERF022 gene is associated with SE induction in Arabidopsis [130]. However, its knock-out, in the erf022 mutant, exhibited a reduced capacity for SE [136]. Confronting these results, it was suggested that ERF022 expression is required to induce SE in Arabidopsis. In this regard, the authors [130] also studied a putative molecular function behind this phenomenon. They reported a downregulation of $A C S 7, E R F 1$, and ETR1 gene expression, suggesting that ERF022 negatively controls ethylene biosynthesis and perception. Furthermore, and even more interestingly, they found that the erf022 mutant exhibited a great inhibition of LEAFY COTYLEDON2 (LEC2) gene expression, along with the impaired capacity of SE induction. LEC2 was reported as a promoter of SE in Arabidopsis via YUCCA-mediated auxin biosynthesis [137]. In line with this, the erf022 mutation was correlated with a downregulation of YUC1 and YUC4 gene expression, along with reduced levels of the endogenous auxin, IAA. This study provides evidence that SE induction from immature zygotic embryos in Arabidopsis is based on an ethylene-auxin crosstalk, mediated by ERF022-LEC2 interaction [130]. 
In the case of alfalfa, a model often used to analyze SE, the embryogenic competence, in the presence of NBD, an inhibitor of ethylene perception, was considerably reduced [110]. Further embryo maturation also decreased in the presence of this ethylene receptor's competitive inhibitor. In another study with this species [111], both embryogenic calli proliferation and somatic embryo maturation decreased in the presence of $50 \mu \mathrm{M}$ AVG. The same group [112] also studied the effect of the inhibitors of ethylene biosynthesis and perception on SE induction in alfalfa (see in detail in Table 1). In agreement with the two last studies, these modulators negatively affected some important SE stages, such as somatic embryo formation, further development, and maturation. AVG and salicylic acid showed a great disruption on somatic embryo development, with a great decrease in the number of somatic embryos in later developmental stages, such as at the cotyledonary stage; in some cases with only globular somatic embryos being observed. Interestingly, in Medicago truncatula (Table 2), a species from the same genus as alfalfa (Medicago sativa), treatments with the ethylene precursors ACC and MGBG increased the number of somatic embryos developed per embryogenic callus, while silver nitrate and AVG greatly decreased the somatic embryo formation [131]. Furthermore, when high silver nitrate and AVG concentrations $(100 \mu \mathrm{M})$ were tested, somatic embryo formation was completely inhibited. Moreover, a positive correlation between ACS and ACO gene expression and the genotype with higher embryo production capacity was found, suggesting that ethylene is required for somatic embryo formation and development in this species [131]. Interestingly, $A C S$ and $A C O$ expression in somatic embryos were found to be similar to the patterns of expression detected in zygotic embryos. The authors also reported an upregulation of ethylene responsive genes when a transcriptional profile analysis of embryogenic calli was carried out. It was found that a member of the ERF family, denominated MtSERF1, was highly expressed in embryogenic calli and strongly expressed in globular somatic embryos. The same gene was weakly associated with low embryogenic capacity. Furthermore, ethylene-dependent MtSERF1 expression was proven by its inhibition with AVG and silver nitrate. These data, together with the fact that silencing MtSERF1 using RNAi completely inhibited the somatic embryo formation [131], proving that ethylene is a key factor during SE induction-probably mediating the action of other hormones, such as auxins and cytokinins. MtSERF1 orthologs genes [113] were found in Arabidopsis thaliana (At5g61590) and soybean (GmSERF1 and GmSERF2), which are involved in the regulation of AGAMOUS-Like15 (AGL15). This gene promotes SE in the SAM of Arabidopsis seedlings [138] and in soybean [139], being upregulated by auxin, in particular, 2,4-D [140]. Ethylene modulation has been tested in both soybean and Arabidopsis SE (see Table 1). The Arabidopsis SAM-SE system [124], is highly promoted by the ethylene precursor ACC, with an increase in number of seedlings with somatic embryos. Furthermore, a reduction in the number of seedlings with embryos was observed in the presence of the inhibitors of ethylene biosynthesis and perception, such as AVG, cobalt chloride, and silver nitrate, suggesting a positive correlation between SE and ethylene. Similar results were observed in different cultivars of soybean, with different embryogenic capacity [113]. The number of somatic embryos increased with ACC treatments and decreased with AVG, with the positive impact of ACC treatments highly marked in the recalcitrant cultivars. The relationships between ethylene/At5g61590/AGL15 and ethylene/GmSERF1/GmAGL15 in the induction of SE of Arabidopsis and soybean, respectively, were confirmed by the transcript accumulation of At5g61590 and GmSERF1 in response to ethylene modulators. Both At5g61590 and GmSERF1 transcript levels were enhanced in ACC treatment, and, in turn, decreased transcript levels of both genes in the presence of inhibitors of ethylene biosynthesis and perception were reported. Transcription levels of AGL15 were also upregulated or downregulated in the presence of ACC or AVG, respectively. Thus, it can be concluded that ethylene regulates SE induced by 2,4-D in Arabidopsis seedlings and in soybean cotyledons, by regulating the ortholog genes of MtSERF1 and subsequent regulation of AGL15, based on an ethylene-auxin crosstalk. Note that ERF022, MtSERF1, At5g61590, and GmSERF1 are all members of the ERF family. 
The effect of ethylene on SE seems also to be species-specific, and within the same species it can affect the regeneration process differently regarding each specific stage (Table 3). For instance, in alfalfa [111,112], ethylene has a stimulatory effect independently of the SE stage, while in spinach [121] ethylene promotes embryogenic calli induction but disrupts somatic embryo development.

Table 3. Differences of ethylene effect depending on the stages of SE. Ethylene showed a stimulatory $(\uparrow)$ or an inhibitory $(\downarrow)$ effect in the respective stages regarding the use of different ethylene modulators.

\begin{tabular}{|c|c|c|c|c|c|}
\hline Plant Species & $\begin{array}{c}\text { Embryogenic } \\
\text { Callus Induction }\end{array}$ & $\begin{array}{c}\text { Embryogenic } \\
\text { Callus Proliferation }\end{array}$ & $\begin{array}{l}\text { Somatic Embryo } \\
\text { Development }\end{array}$ & $\begin{array}{l}\text { Somatic Embryo } \\
\text { Maturation }\end{array}$ & References \\
\hline Alfalfa & $={ }^{\mathrm{a}}$ & $\uparrow$ & $\uparrow$ & $\uparrow$ & {$[111,112]$} \\
\hline $\begin{array}{l}\text { Arabidopsis thaliana; } \\
\text { Carrot; Robusta coffee }\end{array}$ & NA & NA & $\downarrow$ & NA & {$[115,119,120,129]$} \\
\hline $\begin{array}{l}\text { Medicago truncatula; } \\
\text { Soybean }\end{array}$ & NA & NA & $\uparrow$ & NA & {$[113,131]$} \\
\hline Scots pine & NA & NA & $\uparrow$ & $\uparrow$ & [133] \\
\hline Spinach & $\uparrow$ & NA & $\downarrow$ & NA & [121] \\
\hline Summer snowflake & NA & $\downarrow$ & $\uparrow$ & $\uparrow$ & [122] \\
\hline
\end{tabular}

Initial explant and medium compositions are also critical factors to achieve SE. In Arabidopsis seedlings and soybean cotyledons ethylene had a stimulatory effect in somatic embryo formation in the presence of auxins [113], while in an auxin-free medium ethylene disrupted the somatic embryo formation from Arabidopsis' embryogenic calli [129]. Furthermore, in Mendicago truncatula [131] ethylene is essential to promote somatic embryo formation from embryogenic calli in the presence of auxins and cytokinins. Auxins and cytokinins act as stress inducers, leading to SE initiation and callus formation [3]. The role of ethylene in SE in some species seems to be related to stress mediated by ethylene in response to auxin and cytokinins. A possible molecular framework is proposed (Figure 3). Initial stress stimulus by auxins, such as 2,4-D, leads to an increase in ethylene production [130]. An initial increase in ethylene biosynthesis seems to be required for the induction of specific ERF genes [130] essential to induce SE [136]. ERFs stimulate LEC expression [130] and consequent YUC expression, needed for SE induction. Initial higher levels of ethylene (induced by auxins) seem to downregulate YUC levels [129]; however, ethylene levels may tend to decrease over time, as stress levels decrease, leading to a lesser inhibition of YUC. Somatic embryo development can be induced in an auxin-free medium [129], but also in the presence of auxins [113] or auxins plus cytokinins [131]. Based on the studies of Bai et al. [129], in Arabidopsis, an auxin-free medium leads to a downregulation in ethylene levels, and consequent upregulation of YUC levels needed to induce somatic embryo development may be in a stress-independent process. In some species, somatic embryo development can be induced in the presence of stress factors, such as auxins and cytokinins $[113,131]$. In this specific situation, somatic embryo development seems to be induced in a response to stress mediated by ethylene. Ethylene leads to an upregulation of SERF1 gene expression $[113,131]$ with consequent upregulation of AGL15 levels [113]. AGL15 stimulates LEC expression [141] leading to somatic embryo development. Taking into consideration the role of the ERF family in response to stress, ethylene may affect SE differently based on stress-response signaling induced by the hormonal stress caused by auxin and/or cytokinin. 


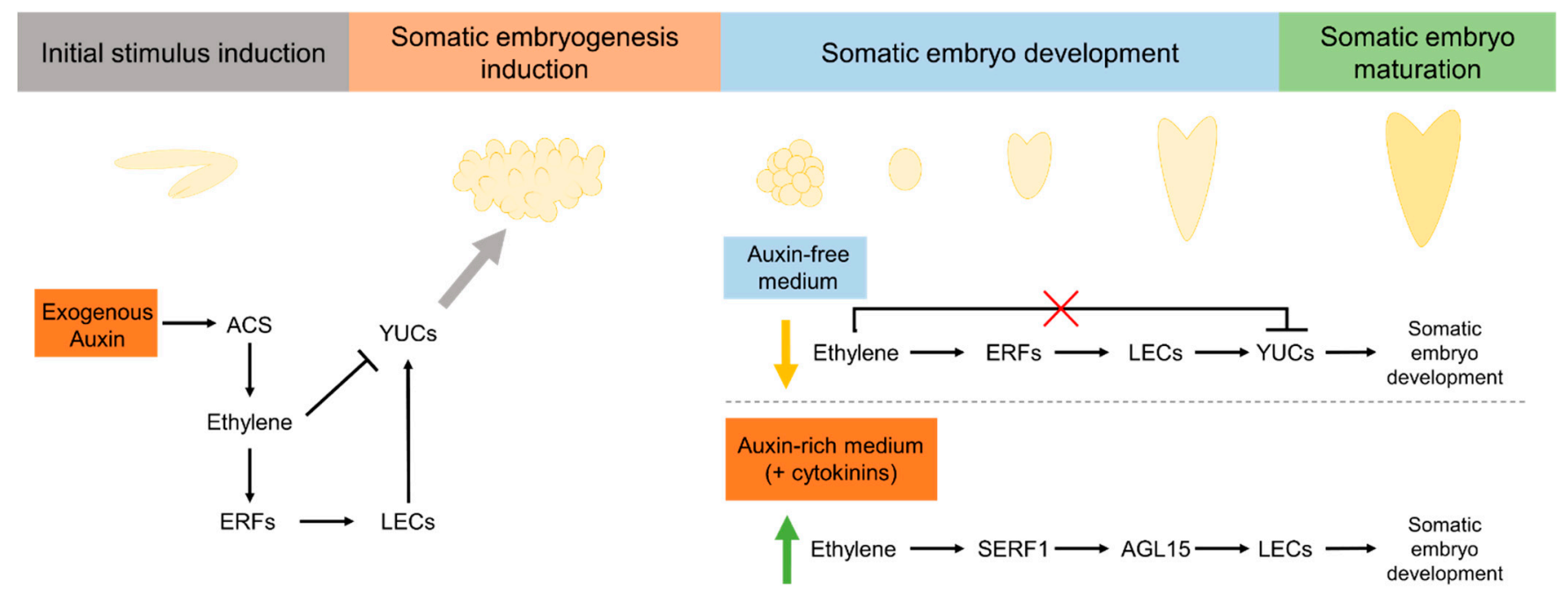

Figure 3. Possible molecular framework for the effect of ethylene on SE process. Exogenous auxins enhance ethylene production in response to stress. Specific transcriptional factors from the ERF family are activated, leading to an increase in LEC and YUC expression levels and consequent SE induction-based on the molecular mechanisms proposed by Nowak et al. [130] in Arabidopsis and the studies of Ikeuchi et al. [3]. In an auxin-free medium, ethylene production decreases, leading to an increase in YUC levels and somatic embryo development—based on Arabidopsis studies [129]. In the presence of auxin, somatic embryo development depends on the specific ERFs to be induced, SERF1 and GL15, perhaps as a consequence of stress induced by auxins and cytokinins—based on studies in Mendicago truncatula [131] and soybean [113].

\section{Conclusions and Future Prospects}

The compiled literature presented here in can give us a great insight into how ethylene affects regeneration processes. It is markedly noted that ethylene affects regeneration depending on the species, the explant, and the stress conditions. We know in advance that a successful regeneration is a requirement to the success of micropropagation processes. Thus, ethylene modulation emerges as imperative regarding the optimization of micropropagation protocols. Modulation of culture conditions such as medium composition and culture atmosphere are some examples that can be further applied when the effect of ethylene on regeneration for each species is known. Moreover, the ethylene capacity in reverting recalcitrance in some species highlights the importance of ethylene modulation studies regarding in vitro regeneration. Further studies focused on the ERF members genes regulated by ethylene in response to stress-induced regeneration can contribute to unveil the mechanisms behind the highly regeneration capacity observed in some genotypes. It may also explain why some genotypes and species are recalcitrant to regeneration. Ethylene seems to affect in vitro regeneration by stress-response signaling, with evident hormonal crosstalk, at least in some species. Considering all the literature, this hormone seems to be an important link between stress, regeneration, and development.

Author Contributions: Original draft preparation: M.N.; conceptualization: J.C., S.C., C.C.; investigation, M.N., S.C., C.C., J.C.; writing-review and editing: J.C., S.C., C.C. All authors have read and agreed to the published version of the manuscript.

Funding: This research was funded by Foundation for Science and Technology (Portugal) who supported Mariana Neves' PhD Fellowship, with reference 2020.05137.BD; ReNATURE project (CENTRO-01-0145) and P2020 I COMPETE grant number PTDC/BAA-AGR/32265/2017, project BP4BP - Tamarillo breeding: better plants for better products. This work was carried out at the R\&D Unit Center for Functional Ecology_-Science for People and the Planet (CFE), with reference UIDB/04004/2020, financed by FCT/MCTES through national funds (PIDDAC). 
Institutional Review Board Statement: Not applicable.

Informed Consent Statement: Not applicable.

Data Availability Statement: Not applicable.

Conflicts of Interest: The authors declare no conflict of interest. The funders had no role in the design of the study; in the collection, analyses, or interpretation of data; in the writing of the manuscript, or in the decision to publish the results.

\section{References}

1. Kumar, N.; Reddy, M.P. In vitro plant propagation: A review. J. For. Sci. 2011, 27, 61-72.

2. Phillips, G.C.; Garda, M. Plant tissue culture media and practices: An overview. Cell. Dev. Biol. Plant 2019, 55, 242-257. [CrossRef]

3. Ikeuchi, M.; Ogawa, Y.; Iwase, A.; Sugimoto, K. Plant regeneration: Cellular origins and molecular mechanisms. Development 2016, 143, 1442-1451. [CrossRef]

4. Bhatia, S.; Bera, T. Somatic embryogenesis and organogenesis. In Modern Applications of Plant Biotechnology in Pharmaceutical Sciences; Bhatia, S., Sharma, K., Dahiya, R., Bera, T., Eds.; Academic Press: Cambridge, MA, USA, 2015; pp. 209-230. [CrossRef]

5. Biddington, N.L. The influence of ethylene in plant tissue culture. Plant Growth Regul. 1992, 11, 173-187. [CrossRef]

6. Iqbal, N.; Khan, N.A.; Ferrante, A.; Trivellini, A.; Francini, A.; Khan, M.I.R. Ethylene role in plant growth, development and senescence: Interaction with other phytohormones. Front. Plant Sci. 2017, 8, 475. [CrossRef] [PubMed]

7. Lieberman, M.; Kunishi, A.; Mapson, L.W.; Wardale, D.A. Stimulation of ethylene production in apple tissue slices by methionine. Plant Physiol. 1966, 41, 376-382. [CrossRef] [PubMed]

8. Adams, D.O.; Yang, S.F. Methionine metabolism in apple tissue: Implication of s-adenosylmethionine as an intermediate in the conversion of methionine to ethylene. Plant Physiol. 1977, 60, 892-896. [CrossRef] [PubMed]

9. Adams, D.O.; Yang, S.F. Ethylene biosynthesis: Identification of 1-aminocyclopropane-1-carboxylic acid as an intermediate in the conversion of methionine to ethylene. Proc. Natl. Acad. Sci. USA 1979, 76, 170-174. [CrossRef]

10. Wang, K.L.; Li, H.; Ecker, J.R. Ethylene biosynthesis and signaling networks. Plant Cell 2002, 14 (Suppl. 1), S131-S151. [CrossRef]

11. Lacey, R.F.; Binder, B.M. How plants sense ethylene gas-The ethylene receptors. J. Inorg. Biochem. 2014, 133, 58-62. [CrossRef]

12. Bleecker, A.B.; Estelle, M.A.; Somerville, C.; Kende, H. Insensitivity to ethylene conferred by a dominant mutation in Arabidopsis thaliana. Science 1988, 241, 1086-1089. [CrossRef]

13. Chang, C.; Kwok, S.F.; Bleecker, A.B.; Meyerowitz, E.M. Arabidopsis ethylene-response gene ETR1: Similarity of product to two-component regulators. Science 1993, 262, 539-544. [CrossRef] [PubMed]

14. Rodriguez, F.I.; Esch, J.J.; Hall, A.E.; Binder, B.M.; Schaller, G.E.; Bleecker, A.B. A copper cofactor for the ethylene receptor ETR1 from Arabidopsis. Science 1999, 283, 996-998. [CrossRef] [PubMed]

15. Binder, B.M. Ethylene signaling in plants. J. Biol. Chem. 2020, 295, 7710-7725. [CrossRef] [PubMed]

16. Ju, C.; Chang, C. Mechanistic Insights in Ethylene Perception and Signal Transduction. Plant Physiol. 2015, 169, 85-95. [CrossRef]

17. Chen, C.; Chen, J.-J. Measurement of gas exchange rates in plant tissue culture vessels. Plant Cell Tiss. Organ Cult. 2002, 71, 103-109. [CrossRef]

18. Huang, C.; Chen, C. Physical properties of culture vessels for plant tissue culture. Biosyst. Eng. 2005, 91, 501-511. [CrossRef]

19. Cristescu, S.M.; Mandon, J.; Arslanov, D.; De Pessemier, J.; Hermans, C.; Harren, F.J. Current methods for detecting ethylene in plants. Ann. Bot. 2013, 111, 347-360. [CrossRef]

20. Huelin, F.E.; Kennett, B.H. Nature of the olefines produced by Apples. Nature 1959, 184, 996. [CrossRef]

21. Jackson, M.B.; Abbott, A.J.; Belcher, A.R.; Hall, K.C.; Butler, R.; Cameron, J. Ventilation in plant tissue cultures and effects of poor aeration on ethylene and carbon dioxide accumulation, oxygen depletion and explant development. Ann. Bot. 1991, 67, $229-237$. [CrossRef]

22. Schaller, G.E.; Binder, B.M. Inhibitors of ethylene biosynthesis and signaling. Methods Mol. Biol. 2017, 1573, 223-235. [CrossRef] [PubMed]

23. Amrhein, N.; Wenker, D. Novel inhibitors of ethylene production in higher plants. Plant Cell Physiol. 1979, $20,1635-1642$. [CrossRef]

24. Yu, Y.-B.; Adams, D.O.; Yang, S.F. 1-Aminocyclopropanecarboxylate synthase, a key enzyme in ethylene biosynthesis. Arch. Biochem. Biophys. 1979, 198, 280-286. [CrossRef]

25. Yu, Y.-B.; Yang, S.F. Auxin-induced ethylene production and its inhibition by aminoethyoxyvinylglycine and cobalt ion. Plant Physiol. 1979, 64, 1074-1077. [CrossRef] [PubMed]

26. John, R.A.; Charteris, A.; Fowler, L.J. The reaction of amino-oxyacetate with pyridoxal phosphate-dependent enzymes. Biochem. J. 1978, 171, 771-779. [CrossRef] [PubMed]

27. Soeno, K.; Goda, H.; Ishii, T.; Ogura, T.; Tachikawa, T.; Sasaki, E.; Yoshida, S.; Fujioka, S.; Asami, T.; Shimada, Y. Auxin biosynthesis inhibitors, identified by a genomics-based approach, provide insights into auxin biosynthesis. Plant Cell Physiol. 2010, 51, 524-536. [CrossRef] 
28. Satoh, S.; Esashi, Y. $\alpha$-Aminoisobutyric acid: A probable competitive inhibitor of conversion of 1-aminocyclopropane-1-carboxylic acid to ethylene. Plant Cell Physiol. 1980, 21, 939-949. [CrossRef]

29. Satoh, S.; Esashi, Y. $\alpha$-Aminoisabutyric acid, propyl gallate and cobalt ion and the mode of inhibition of ethylene production by cotyledonary segments of cocklebur seeds. Physiol. Plant. 1983, 57, 521-526. [CrossRef]

30. Houben, M.; Van de Poel, B. 1-Aminocyclopropane-1-carboxylic acid oxidase (ACO): The enzyme that makes the plant hormone ethylene. Front. Plant Sci. 2019, 10, 695. [CrossRef]

31. Dilley, D.R.; Kuai, J.; Poneleit, L.; Pekker, Y.; Wilson, I.D.; Burmeister, D.M.; Gran, C.; Bowers, A. Purification and characterization of ACC oxidase and its expression during ripening in apple fruit. In Cellular and Molecular Aspects of the Plant Hormone Ethylene. Current Plant Science and Biotechnology in Agriculture; Pech, J.C., Latché, A., Balagué, C., Eds.; Springer: Dordrecht, The Netherlands, 1993; pp. 46-52.

32. Leslie, C.A.; Romani, R.J. Salicylic acid: A new inhibitor of ethylene biosynthesis. Plant Cell Rep. 1986, 5, 144-146. [CrossRef]

33. Lin, L.C.; Hsu, J.H.; Wang, L.C. Identification of novel inhibitors of 1-aminocyclopropane-1-carboxylic acid synthase by chemical screening in Arabidopsis thaliana. J. Biol. Chem. 2010, 285, 33445-33456. [CrossRef]

34. Sun, X.; Li, Y.; He, W.; Ji, C.; Xia, P.; Wang, Y.; Du, S.; Li, H.; Raikhel, N.; Xiao, J.; et al. Pyrazinamide and derivatives block ethylene biosynthesis by inhibiting ACC oxidase. Nat. Commun. 2017, 8, 15758. [CrossRef]

35. Beyer, E.M. A potent inhibitor of ethylene action in plants. Plant Physiol. 1976, 58, 268-271. [CrossRef]

36. Binder, B.M.; Rodriguez, F.I.; Bleecker, A.B.; Patterson, S.E. The effects of Group 11 transition metals, including gold, on ethylene binding to the ETR1 receptor and growth of Arabidopsis thaliana. FEBS Lett. 2007, 581, 5105-5109. [CrossRef] [PubMed]

37. McDaniel, B.K.; Binder, B.M. Ethylene receptor 1 (ETR1) is sufficient and has the predominant role in mediating inhibition of ethylene responses by silver in Arabidopsis thaliana. J. Biol. Chem. 2012, 287, 26094-26103. [CrossRef] [PubMed]

38. Vishwakarma, K.; Upadhyay, N.; Singh, J.; Liu, S.; Singh, V.P.; Prasad, S.M.; Chauhan, D.K.; Tripathi, D.K.; Sharma, S. Differential phytotoxic impact of plant mediated silver nanoparticles (AgNPs) and silver nitrate $\left(\mathrm{AgNO}_{3}\right)$ on Brassica sp. Front. Plant Sci. 2017, 8, 1501. [CrossRef] [PubMed]

39. Cvjetko, P.; Zovko, M.P.; Štefanić, P.; Biba, R.; Tkalec, M.; Domijan, A.-M.; Vrček, I.V.; Letofsky-Papst, I.; Šikić, S.; Balen, B. Phytotoxic effects of silver nanoparticles in tobacco plants. Environ. Sci. Pollut. Res. 2018, 25, 5590-5602. [CrossRef]

40. Karimi, J.; Mohsenzadeh, S. Physiological effects of silver nanoparticles and silver nitrate toxicity in Triticum aestivum. Iran. J. Sci. Technol. Trans. A Sci. 2017, 41, 111-120. [CrossRef]

41. Jiang, H.S.; Li, M.; Chang, F.Y.; Li, W.; Yin, L.Y. Physiological analysis of silver nanoparticles and $\mathrm{AgNO}_{3}$ toxicity to Spirodela polyrhiza. Environ. Toxicol. Chem. 2012, 31, 1880-1886. [CrossRef]

42. Strader, L.C.; Beisner, E.R.; Bartel, B. Silver ions increase auxin efflux independently of effects on ethylene response. Plant Cell 2009, 21, 3585-3590. [CrossRef]

43. Sisler, E.C. The discovery and development of compounds counteracting ethylene at the receptor level. Biotechnol. Adv. 2006, 24, 357-367. [CrossRef]

44. Lürssen, K.; Naumann, K.; Schröder, R. 1-Aminocyclopropane-1-carboxylic acid-an intermediate of the ethylene biosynthesis in higher plants. Z. Pflanzenphysiol. 1979, 92, 285-294. [CrossRef]

45. Yang, S.F. Ethylene evolution from 2-chloroethylphosphonic acid. Plant Physiol. 1969, 44, 1203-1204. [CrossRef] [PubMed]

46. Lee, M.M.; Lee, S.H.; Park, K.Y. Effects of spermine on ethylene biosynthesis in cut carnation (Dianthus caryophyllus L.) flowers during senescence. J. Plant Physiol. 1997, 151, 68-73. [CrossRef]

47. Young, R.E.; Pratt, H.K.; Biale, J.B. Manometric determination of low concentrations of ethylene with particular reference to plant material. Anal. Chem. 1952, 24, 551-555. [CrossRef]

48. Nelson, R.C. Studies on production of ethylene in the ripening process in apple and banana. J. Food Sci. 1939, 4, 173-190. [CrossRef]

49. Stearns, J.C.; Glick, B.R. Transgenic plants with altered ethylene biosynthesis or perception. Biotechnol. Adv. 2003, 21, 193-210. [CrossRef]

50. Guzmán, P.; Ecker, J.R. Exploiting the triple response of Arabidopsis to identify ethylene-related mutants. Plant Cell 1990, 2, 513-523. [CrossRef]

51. Zhao, X.C.; Qu, X.; Mathews, D.E.; Schaller, G.E. Effect of ethylene pathway mutations upon expression of the ethylene receptor ETR1 from Arabidopsis. Plant Physiol. 2002, 130, 1983-1991. [CrossRef] [PubMed]

52. Kieber, J.J.; Rothenberg, M.; Roman, G.; Feldmann, K.A.; Ecker, J.R. CTR1, a negative regulator of the ethylene response pathway in Arabidopsis, encodes a member of the raf family of protein kinases. Cell 1993, 72, 427-441. [CrossRef]

53. Chae, H.S.; Faure, F.; Kieber, J.J. The eto1, eto2, and eto3 mutations and cytokinin treatment increase ethylene biosynthesis in Arabidopsis by increasing the stability of ACS protein. Plant Cell 2003, 15, 545-559. [CrossRef] [PubMed]

54. Hall, A.E.; Chen, Q.G.; Findell, J.L.; Schaller, G.E.; Bleecker, A.B. The relationship between ethylene binding and dominant insensitivity conferred by mutant forms of the ETR1 ethylene receptor. Plant Physiol. 1999, 121, 291-299. [CrossRef]

55. Roman, G.; Lubarsky, B.; Kieber, J.J.; Rothenberg, M.; Ecker, J.R. Genetic analysis of ethylene signal transduction in Arabidopsis thaliana: Five novel mutant loci integrated into a stress response pathway. Genetics 1995, 139, 1393-1409. [CrossRef] [PubMed] 
56. Sakai, H.; Hua, J.; Chen, Q.G.; Chang, C.; Medrano, L.J.; Bleecker, A.B.; Meyerowitz, E.M. ETR2 is an ETR1-like gene involved in ethylene signaling in Arabidopsis. Proc. Natl. Acad. Sci. USA 1998, 95, 5812-5817. [CrossRef] [PubMed]

57. Vogel, J.P.; Woeste, K.E.; Theologis, A.; Kieber, J.J. Recessive and dominant mutations in the ethylene biosynthetic gene ACS5 of Arabidopsis confer cytokinin insensitivity and ethylene overproduction, respectively. Proc. Natl. Acad. Sci. USA 1998, 95, 4766-4771. [CrossRef] [PubMed]

58. Czarny, J.C.; Grichko, V.P.; Glick, B.R. Genetic modulation of ethylene biosynthesis and signaling in plants. Biotechnol. Adv. 2006, 24, 410-419. [CrossRef]

59. Ruduś, I.; Sasiak, M.; Kęczyński, J. Regulation of ethylene biosynthesis at the level of 1-aminocyclopropane-1-carboxylate oxidase (ACO) gene. Acta Physiol. Plant. 2013, 35, 295-307. [CrossRef]

60. Love, J.; Bjorklund, S.; Vahala, J.; Hertzberg, M.; Kangasjarvi, J.; Sundberg, B. Ethylene is an endogenous stimulator of cell division in the cambial meristem of Populus. Proc. Natl. Acad. Sci. USA 2009, 106, 5984-5989. [CrossRef]

61. Tu, Y.; He, B.; Gao, S.; Guo, D.; Jia, X.; Dong, X.; Guo, M. CtACO1 Overexpression resulted in the alteration of the flavonoids profile of safflower. Molecules 2009, 24, 1128. [CrossRef]

62. Feng, Z.; Zhang, B.; Ding, W.; Liu, X.; Yang, D.L.; Wei, P.; Cao, F.; Zhu, S.; Zhang, F.; Mao, Y.; et al. Efficient genome editing in plants using a CRISPR/Cas system. Cell Res. 2013, 23, 1229-1232. [CrossRef]

63. Xu, J.; Kang, B.C.; Naing, A.H.; Bae, S.J.; Kim, J.S.; Kim, H.; Kim, C.K. CRISPR/Cas9-mediated editing of 1-aminocyclopropane-1carboxylate oxidase1 enhances Petunia flower longevity. Plant Biotechnol. J. 2020, 18, 287-297. [CrossRef]

64. Pikaard, C.S.; Mittelsten Scheid, O. Epigenetic regulation in plants. Cold Spring Harb. Perspect. Biol. 2014, 6, a019315. [CrossRef]

65. Yan, X.; Ma, L.; Pang, H.; Wang, P.; Liu, L.; Cheng, Y.; Cheng, J.; Guo, Y.; Li, Q. METHIONINE SYNTHASE1 is involved in chromatin silencing by maintaining DNA and histone methylation. Plant Physiol. 2019, 181, 249-261. [CrossRef] [PubMed]

66. Meng, J.; Wang, L.; Wang, J.; Zhao, X.; Cheng, J.; Yu, W.; Jin, D.; Li, Q.; Gong, Z. METHIONINE ADENOSYLTRANSFERASE4 mediates dna and histone methylation. Plant Physiol. 2018, 177, 652-670. [CrossRef]

67. Wang, L.; Zhang, F.; Qiao, H. Chromatin regulation in the response of ethylene: Nuclear events in ethylene signaling. Small Methods 2019, 4, 1900288. [CrossRef]

68. Zhang, N. Role of methionine on epigenetic modification of DNA methylation and gene expression in animals. Anim. Nutr. 2018, 4, 11-16. [CrossRef] [PubMed]

69. Lindermayr, C.; Rudolf, E.E.; Durner, J.; Groth, M. Interactions between metabolism and chromatin in plant models. Mol. Metab. 2020, 38, 100951. [CrossRef]

70. Li, W.; Han, Y.; Tao, F.; Chong, K. Knockdown of SAMS genes encoding S-adenosyl-l-methionine synthetases causes methylation alterations of DNAs and histones and leads to late flowering in rice. J. Plant Physiol. 2011, 168, 1837-1843. [CrossRef] [PubMed]

71. Lee, K.; Seo, P.J. Dynamic epigenetic changes during plant regeneration. Trends Plant Sci. 2018, 23, 235-247. [CrossRef]

72. Zhang, F.; Qi, B.; Wang, L.; Zhao, B.; Rode, S.; Riggan, N.D.; Ecker, J.R.; Qiao, H. EIN2-dependent regulation of acetylation of histone H3K14 and non-canonical histone H3K23 in ethylene signalling. Nat. Commun. 2016, 7, 13018. [CrossRef] [PubMed]

73. Wang, L.; Zhang, F.; Rode, S.; Chin, K.K.; Ko, E.E.; Kim, J.; Iyer, V.R.; Qiao, H. Ethylene induces combinatorial effects of histone $\mathrm{H} 3$ acetylation in gene expression in Arabidopsis. BMC Genom. 2017, 18, 538. [CrossRef]

74. Zhang, F.; Wang, L.; Qi, B.; Zhao, B.; Ko, E.E.; Riggan, N.D.; Chin, K.; Qiao, H. EIN2 mediates direct regulation of histone acetylation in the ethylene response. Proc. Natl. Acad. Sci. USA 2017, 114, 10274-10279. [CrossRef] [PubMed]

75. Wang, L.; Zhang, Z.; Zhang, F.; Shao, Z.; Zhao, B.; Huang, A.; Tran, J.; Hernandez, F.V.; Qiao, H. EIN2-directed histone acetylation requires EIN3-mediated positive feedback regulation in response to ethylene. Plant Cell 2020, 33, 322-337. [CrossRef] [PubMed]

76. Khann, N.A.; Khann, M.I.I.; Ferrante, A.; Poor, P. Ethylene: A key regulator molecule in plants. Front. Plant Sci. $2017,8,1782$. [CrossRef] [PubMed]

77. Lardon, R.; Geelen, D. Natural variation in plant pluripotency and regeneration. Plants 2020, 9, 1261. [CrossRef]

78. Sangwan, R.S.; Harada, H. Chemical regulation of callus growth, organogenesis, plant regeneration, and somatic embryogenesis in Antirrhinum majus tissue and cell cultures. J. Exp. Bot. 1975, 26, 868-881. [CrossRef]

79. Khanam, N.; Khoo, C.; Khan, A.G. Effects of cytokinin/auxin combinations on organogenesis, shoot regeneration and tropane alkaloid production in Duboisia myoporoides. Plant Cell Tiss. Organ Cult. 2000, 62, 125-133. [CrossRef]

80. Cheng, Z.J.; Wang, L.; Sun, W.; Zhang, Y.; Zhou, C.; Su, Y.H.; Li, W.; Sun, T.T.; Zhao, X.Y.; Li, X.G.; et al. Pattern of auxin and cytokinin responses for shoot meristem induction results from the regulation of cytokinin biosynthesis by AUXIN RESPONSE FACTOR3. Plant Physiol. 2013, 161, 240-251. [CrossRef]

81. Gaj, M.D. Factors influencing somatic embryogenesis induction and plant regeneration with particular reference to Arabidopsis thaliana (L.) Heynh. Plant Growth Reg. 2004, 43, 27-47. [CrossRef]

82. Feher, A. Somatic embryogenesis-Stress-induced remodeling of plant cell fate. Biochim. Biophys. Acta 2015, 1849, 385-402. [CrossRef]

83. Swarup, R.; Perry, P.; Hagenbeek, D.; Van Der Straeten, D.; Beemster, G.T.; Sandberg, G.; Bhalerao, R.; Ljung, K.; Bennett, M.J. Ethylene upregulates auxin biosynthesis in Arabidopsis seedlings to enhance inhibition of root cell elongation. Plant Cell 2007, 19, 2186-2196. [CrossRef]

84. Ruzicka, K.; Ljung, K.; Vanneste, S.; Podhorska, R.; Beeckman, T.; Friml, J.; Benkova, E. Ethylene regulates root growth through effects on auxin biosynthesis and transport-dependent auxin distribution. Plant Cell 2007, 19, 2197-2212. [CrossRef] [PubMed] 
85. Lewis, D.R.; Negi, S.; Sukumar, P.; Muday, G.K. Ethylene inhibits lateral root development, increases IAA transport and expression of PIN3 and PIN7 auxin efflux carriers. Development 2011, 138, 3485-3495. [CrossRef]

86. Li, W.; Nishiyama, R.; Watanabe, Y.; Van Ha, C.; Kojima, M.; An, P.; Tian, L.; Tian, C.; Sakakibara, H.; Tran, L.P. Effects of overproduced ethylene on the contents of other phytohormones and expression of their key biosynthetic genes. Plant Physiol. Biochem. 2018, 128, 170-177. [CrossRef]

87. Vandenbussche, F.; Petrasek, J.; Zadnikova, P.; Hoyerova, K.; Pesek, B.; Raz, V.; Swarup, R.; Bennett, M.; Zazimalova, E.; Benkova, E.; et al. The auxin influx carriers AUX1 and LAX3 are involved in auxin-ethylene interactions during apical hook development in Arabidopsis thaliana seedlings. Development 2010, 137, 597-606. [CrossRef] [PubMed]

88. Muday, G.K.; Rahman, A.; Binder, B.M. Auxin and ethylene: Collaborators or competitors? Trends Plant Sci. 2012, 17, 181-195. [CrossRef]

89. Tsuchisaka, A.; Theologis, A. Unique and overlapping expression patterns among the Arabidopsis 1-amino-cyclopropane-1carboxylate synthase gene family members. Plant Physiol. 2004, 136, 2982-3000. [CrossRef] [PubMed]

90. Salman-Minkov, A.; Levi, A.; Wolf, S.; Trebitsh, T. ACC synthase genes are polymorphic in watermelon (Citrullus spp.) and differentially expressed in flowers and in response to auxin and gibberellin. Plant Cell Physiol. 2008, 49, 740-750. [CrossRef]

91. Hansen, M.; Chae, H.S.; Kieber, J.J. Regulation of ACS protein stability by cytokinin and brassinosteroid. Plant J. 2009, 57, 606-614. [CrossRef]

92. Ikeuchi, M.; Iwase, A.; Rymen, B.; Lambolez, A.; Kojima, M.; Takebayashi, Y.; Heyman, J.; Watanabe, S.; Seo, M.; De Veylder, L.; et al. Wounding triggers callus formation via dynamic hormonal and transcriptional changes. Plant Physiol. 2017, 175, 1158-1174. [CrossRef]

93. Correia, S.; Lopes, M.L.; Canhoto, J.M. Somatic embryogenesis induction system for cloning an adult Cyphomandra betacea (Cav.) Sendt. (tamarillo). Trees 2011, 25, 1009-1020. [CrossRef]

94. Martins, J.F.; Correia, S.I.; Canhoto, J.M. Somatic embryogenesis induction and plant regeneration in strawberry tree (Arbutus unedo L.). In Methods in Molecular Biology; Germana, M., Lambardi, M., Eds.; Humana Press: New York, NY, USA, 2016; Volume 1359, pp. 329-339. [CrossRef]

95. Boller, T.; Kende, H. Regulation of wound ethylene synthesis in plants. Nature 1980, 286, 259-260. [CrossRef]

96. Ke, D.; Saltveit, M.E., Jr. Wound-induced ethylene production, phenolic metabolism and susceptibility to russet spotting in Iceberg lettuce. Physiol. Plant. 1989, 76, 412-418. [CrossRef]

97. Hyodo, H.; Tanaka, K.; Suzuki, T. Wound-induced ethylene synthesis and its involvement in enzyme induction in mesocarp tissue of Cucurbita maxima. Postharvest Biol. Technol. 1991, 1, 127-136. [CrossRef]

98. Rojo, E.; León, J.; Sánchez-Serrano, J.J. Cross-talk between wound signalling pathways determines local versus systemic gene expression in Arabidopsis thaliana. Plant J. 1999, 20, 135-142. [CrossRef] [PubMed]

99. Park, M.J.; Park, C.-J.; Lee, S.-B.; Ham, B.-K.; Shin, R.; Paek, K.-H. Overexpression of the tobacco Tsi1 gene encoding an EREBP/AP2-type transcription factor enhances resistance against pathogen attack and osmotic stress in tobacco. Plant Cell 2001, 13, 1035-1046. [CrossRef]

100. Boex-Fontvieille, E.; Rustgi, S.; von Wettstein, D.; Pollmann, S.; Reinbothe, S.; Reinbothe, C. An ethylene-protected Achilles' heel of etiolated seedlings for arthropod deterrence. Front. Plant Sci. 2016, 7, 1246. [CrossRef]

101. Wang, S.; Park, Y.S.; Yang, Y.; Borrego, E.J.; Isakeit, T.; Gao, X.; Kolomiets, M.V. Seed-Derived Ethylene Facilitates Colonization but Not Aflatoxin Production by Aspergillus flavus in Maize. Front. Plant Sci. 2017, 8, 415. [CrossRef] [PubMed]

102. Cheng, M.C.; Liao, P.M.; Kuo, W.W.; Lin, T.P. The Arabidopsis ETHYLENE RESPONSE FACTOR1 regulates abiotic stressresponsive gene expression by binding to different cis-acting elements in response to different stress signals. Plant Physiol. 2013, 162, 1566-1582. [CrossRef]

103. Dubois, M.; Skirycz, A.; Claeys, H.; Maleux, K.; Dhondt, S.; De Bodt, S.; Vanden Bossche, R.; De Milde, L.; Yoshizumi, T.; Matsui, M.; et al. Ethylene Response Factor6 acts as a central regulator of leaf growth under water-limiting conditions in Arabidopsis. Plant Physiol. 2013, 162, 319-332. [CrossRef]

104. Kumar, P.P.; Lakshmanan, P.; Thorpe, T.A. Regulation of morphogenesis in plant tissue culture by ethylene. Cell. Dev. Biol. Plant 1998, 34, 94-103. [CrossRef]

105. Chae, S.C.; Kim, H.H.; Park, S.U. Ethylene inhibitors enhance shoot organogenesis of gloxinia (Sinningia speciosa). Sci. World J. 2012, 2012, 859381. [CrossRef] [PubMed]

106. Roustan, J.-P.; Latche, A.; Fallot, J. Enhancement of shoot regeneration from cotyledons of Cucumis melo by AgNO3, an inhibitor of ethylene action. J. Plant Physiol. 1992, 140, 485-488. [CrossRef]

107. Amor, M.B.; Guis, M.; Latché, A.; Bouzayen, M.; Pech, J.C.; Roustan, J.P. Expression of an antisense 1-aminocyclopropane-1carboxylate oxidase gene stimulates shoot regeneration in Cucumis melo. Plant Cell Rep. 1998, 17, 586-589. [CrossRef] [PubMed]

108. Paladi, R.K.; Rai, A.N.; Penna, S. Silver nitrate modulates organogenesis in Brassica juncea (L.) through differential antioxidant defense and hormonal gene expression. Sci. Horti. 2017, 226, 261-267. [CrossRef]

109. Pua, E.-C.; Chi, G.-L. De novo shoot morphogenesis and plant growth of mustard (Brassica juncea) in vitro in relation to ethylene. Physiol. Plant. 1993, 88, 467-474. [CrossRef]

110. Kepczyński, J.; McKersie, B.D.; Brown, D.C.W. Requirement of ethylene for growth of callus and somatic embryogenesis in Medicago sativa L. J. Exp. Bot. 1992, 43, 1199-1202. [CrossRef] 
111. Kępczyńska, E.; Ruduś, I.; Kępczyński, J. Endogenous ethylene in indirect somatic embryogenesis of Medicago sativa L. Plant Growth Regul. 2009, 59, 63-73. [CrossRef]

112. Kępczyńska, E.; Zielińska, S. Disturbance of ethylene biosynthesis and perception during somatic embryogenesis in Medicago sativa L. reduces embryos' ability to regenerate. Acta Physiol. Plant. 2011, 33, 1969-1980. [CrossRef]

113. Zheng, Q.; Zheng, Y.; Perry, S.E. AGAMOUS-Like15 promotes somatic embryogenesis in Arabidopsis and soybean in part by the control of ethylene biosynthesis and response. Plant Physiol. 2013, 161, 2113-2127. [CrossRef]

114. Meskaoui, A.E.; Tremblay, F.M. Involvement of ethylene in the maturation of black spruce embryogenic cell lines with different maturation capacities. J. Exp. Bot. 2001, 52, 761-769. [CrossRef]

115. Roustan, J.P.; Latche, A.; Fallot, J. Stimulation of Daucus carota somatic embryogenesis by inhibitors of ethylene synthesis: Cobalt and nickel. Plant Cell Rep. 1989, 8, 182-185. [CrossRef] [PubMed]

116. Navarro-García, N.; Martínez-Romero, D.; Pérez-Tornero, O. Assessment of the impact of ethylene and ethylene modulators in Citrus limon organogenesis. Plant Cell Tiss. Organ Cult. 2016, 127, 405-415. [CrossRef]

117. Reis, L.B.; Paiva Neto, V.B.; Toledo Picoli, E.A.; Costa, M.G.C.; Rêgo, M.M.; Carvalho, C.R.; Finger, F.L.; Otoni, W.C. Axillary bud development of passionfruit as affected by ethylene precursor and inhibitors. Cell. Dev. Biol. Plant 2003, 39, 618-622. [CrossRef]

118. Gonzalez, A.; Arigita, L.; Majada, J.; Sánchez Tamés, R. Ethylene involvement in in vitro organogenesis and plant growth of Populus tremula L. Plant Growth Regul. 1997, 22, 1-6. [CrossRef]

119. Fuentes, S.R.; Calheiros, M.B.; Manetti-Filho, J.; Vieira, L.G. The effects of silver nitrate and different carbohydrate sources on somatic embryogenesis in Coffea canephora. Plant Cell Tiss. Organ Cult. 2000, 60, 5-13. [CrossRef]

120. Kumar, V.; Ramakrishna, A.; Ravishankar, G.A. Influence of different ethylene inhibitors on somatic embryogenesis and secondary embryogenesis from Coffea canephora P ex Fr. Cell. Dev. Biol. Plant 2007, 43, 602-607. [CrossRef]

121. Ishizaki, T.; Komai, F.; Msuda, K.; Megumi, C. Exogenous ethylene enhances formation of embryogenic callus and inhibits embryogenesis in cultures of explants of spinach roots. J. Amer. Soc. Hortic. Sci. 2000, 125, 21-24. [CrossRef]

122. Ptak, A.; Tahchy, A.E.; Wyżgolik, G.; Henry, M.; Laurain-Mattar, D. Effects of ethylene on somatic embryogenesis and galanthamine content in Leucojum aestivum L. cultures. Plant Cell Tiss. Organ Cult. 2010, 102, 61-67. [CrossRef]

123. Trujillo-Moya, C.; Gisbert, C. The influence of ethylene and ethylene modulators on shoot organogenesis in tomato. Plant Cell Tiss. Organ Cult. 2012, 111, 41-48. [CrossRef]

124. Mordhorst, A.P.; Voerman, K.J.; Hartog, M.V.; Meijer, E.A.; van Went, J.; Koornneef, M.; de Vries, S.C. Somatic embryogenesis in Arabidopsis thaliana is facilitated by mutations in genes repressing meristematic cell divisions. Genetics 1998, 149, 549-563. [CrossRef]

125. Pua, E.-C.; Lee, J.E.E. Enhanced de novo shoot morphogenesis in vitro by expression of antisense 1-aminocyclopropane-1carboxylate oxidase gene in transgenic mustard plants. Planta 1995, 196, 69-76. [CrossRef]

126. Chatfield, S.P.; Raizada, M.N. Ethylene and shoot regeneration: hookless1 modulates de novo shoot organogenesis in Arabidopsis thaliana. Plant Cell Rep. 2008, 27, 655-666. [CrossRef]

127. Hatanaka, T.; Sawabe, E.; Azuma, T.; Uchida, N.; Yasuda, T. The role of ethylene in somatic embryogenesis from leaf discs of Coffea canephora. Plant Sci. 1995, 107, 199-204. [CrossRef]

128. Neves, M. Effect of Ethylene on Somatic Embryogenesis of Tamarillo (Solanum betaceum Cav.). Master's Thesis, University of Coimbra, Coimbra, Portugal, 2018. Available online: http://hdl.handle.net/10316/86197 (accessed on 4 April 2021).

129. Bai, B.; Su, Y.H.; Yuan, J.; Zhang, X.S. Induction of somatic embryos in Arabidopsis requires local YUCCA expression mediated by the down-regulation of ethylene biosynthesis. Mol. Plant 2013, 6, 1247-1260. [CrossRef] [PubMed]

130. Nowak, K.; Wojcikowska, B.; Gaj, M.D. ERF022 impacts the induction of somatic embryogenesis in Arabidopsis through the ethylene-related pathway. Planta 2015, 241, 967-985. [CrossRef] [PubMed]

131. Mantiri, F.R.; Kurdyukov, S.; Lohar, D.P.; Sharopova, N.; Saeed, N.A.; Wang, X.D.; Vandenbosch, K.A.; Rose, R.J. The transcription factor MtSERF1 of the ERF subfamily identified by transcriptional profiling is required for somatic embryogenesis induced by auxin plus cytokinin in Medicago truncatula. Plant Physiol. 2008, 146, 1622-1636. [CrossRef]

132. Zobayed, S.M.A.; Armstrong, J.; Armstrong, W. Micropropagation of potato: Evaluation of closed, diffusive and forced ventilation on growth and tuberization. Ann. Bot. 2001, 87, 53-59. [CrossRef]

133. Lu, J.; Vahala, J.; Pappinen, A. Involvement of ethylene in somatic embryogenesis in Scots pine (Pinus sylvestris L.). Plant Cell Tiss. Organ Cult. 2011, 107, 25-33. [CrossRef]

134. Zhao, Y.; Christensen, S.K.; Fankhauser, C.; Cashman, J.R.; Cohen, J.D.; Weigel, D.; Chory, J. A role for flavin monooxygenase-like enzymes in auxin biosynthesis. Science 2001, 291, 306-309. [CrossRef] [PubMed]

135. Xu, Z.-S.; Chen, M.; Li, L.-C.; Ma, Y.-Z. Functions of the ERF transcription factor family in plants. Botany 2008, 86, 969-977. [CrossRef]

136. Gliwicka, M.; Nowak, K.; Balazadeh, S.; Mueller-Roeber, B.; Gaj, M.D. Extensive modulation of the transcription factor transcriptome during somatic embryogenesis in Arabidopsis thaliana. PLoS ONE 2013, 8, e69261. [CrossRef] [PubMed]

137. Wojcikowska, B.; Jaskola, K.; Gasiorek, P.; Meus, M.; Nowak, K.; Gaj, M.D. LEAFY COTYLEDON2 (LEC2) promotes embryogenic induction in somatic tissues of Arabidopsis, via YUCCA-mediated auxin biosynthesis. Planta 2013, 238, 425-440. [CrossRef] [PubMed] 
138. Harding, E.W.; Tang, W.; Nichols, K.W.; Fernandez, D.E.; Perry, S.E. Expression and maintenance of embryogenic potential is enhanced through constitutive expression of AGAMOUS-Like 15. Plant Physiol. 2003, 133, 653-663. [CrossRef] [PubMed]

139. Thakare, D.; Tang, W.; Hill, K.; Perry, S.E. The MADS-domain transcriptional regulator AGAMOUS-LIKE15 promotes somatic embryo development in Arabidopsis and soybean. Plant Physiol. 2008, 146, 1663-1672. [CrossRef] [PubMed]

140. Zhu, C.; Perry, S.E. Control of expression and autoregulation of AGL15, a member of the MADS-box family. Plant J. 2005, 41, 583-594. [CrossRef] [PubMed]

141. Zheng, Y.; Ren, N.; Wang, H.; Stromberg, A.J.; Perry, S.E. Global identification of targets of the Arabidopsis MADS domain protein AGAMOUS-Like15. Plant Cell 2009, 21, 2563-2577. [CrossRef] 